\title{
Pannonian (late Miocene) ostracod fauna from Pécs-Danitzpuszta in Southern Hungary
}

\author{
Csoma, Vivien ${ }^{1}$, Magyar, Imre ${ }^{2,3}$, Szuromi-Korecz, Andrea ${ }^{3}$, Sebe, Krisztina ${ }^{4}$, Sztanó, Orsolya $^{5}$, \\ BuczKó, Krisztina $^{6}$, TótH, Emőke ${ }^{1}$
}

'ELTE Eötvös Loránd University, Institute of Geography and Earth Sciences, Department of Palaeontology, 1117 Budapest, Pázmány Péter sétány 1/c, Hungary.csoma.vivien7@ gmail.com, ORCID: 0000-0002-2593-5537; tothemoke.pal@ gmail.com; ORCID: 0000-0002-1733-7828 ${ }^{2}$ MTA-MTM-ELTE Research Group for Paleontology, Budapest, Hungary

${ }^{3}$ MOL Hungarian Oil and Gas Plc., Budapest, Hungary; immagyar@mol.hu; orcid.org/0000- 0002-9236-0040; kaszuro@mol.hu

${ }^{4}$ University of Pécs, Department of Geology and Meteorology, 7624 Pécs, Ifjúság útja 6, Hungary; sebe@ gamma.ttk.pte.hu; ORCID: 0000-0002-4647-2199

${ }^{5}$ Dept. of Geology, ELTE Eötvös Loránd University, Institute of Geography and Earth Sciences, Budapest, sztano@ caesar.elte.hu; orcid.org/0000-0003-0786-3653

${ }^{6}$ Hungarian Natural History Museum, Department of Botany, Institute of Aquatic Ecology Centre for Ecological Research, 1113 Budapest, Karolina út 29. , krisztina@ buczko.eu, orcid:0000-0001-9459-8311

\section{Pannóniai kagylósrák fauna Pécs-Danitzpusztáról}

Összefoglalás

A pécs-danitzpusztai homokbányában, a kitermelt homok feküjében egy tektonikailag erősen kibillentett pannóniai márga rétegsor tárul fel. Az összlet vastagsága 65 m a szarmata-pannóniai határtól a fedő homokig. Ez a bányaudvar a pannóniai emelet aljának legjobb, rétegtanilag legteljesebb felszíni feltárása Magyarországon, ezért komplex ôslénytani, rétegtani feldolgozása nemzetközi jelentőségú. Tanulmányunk a rétegsor kagylósrák-maradványainak vizsgálatáról szól. 45 preparált kőzetmintából 29 tartalmazott értékelhető, jó megtartású kagylósrák faunát, összesen 39 taxont, amelyek 9 nemet képviselnek.

A ma is élő, tengeri eredetű nemek (Loxoconcha, Cyprideis, Amnicythere) élőhelyeit figyelembe véve a vizsgált együttesek aránylag sekély, de hullámbázis alatti, alacsony energiájú, csendes környezetben, pliohalin (9-16\%o) sótartalmú vízben élhettek. Az édesvízi eredetú bevándorlók közül a Candona-nem különböző alnemei nyilvánvalóan elviselték a brakkvizet is, ahogy azt a ma is élő Typhlocypris subgenus esetében látjuk. Ugyanez igaz lehetett arra a néhány Cypria fajra is, amelyek nagyon elterjedtek voltak a Pannon-tóban. A Herpetocyprella-nem, amelynek csak egyetlen éló faját ismerjük, de amely szintén igen elterjedt volt a Pannon-tóban, a bezáró kőzetek fáciesei alapján erősen tágtúrésú lehetett. A kihalt nemek (Hemicytheria, Loxocorniculina, Amplocypris) mind brakkvízi környezetben (a szarmata Paratethysben vagy brakkvízi tavakban) éltek.

Biosztratigráfiailag négy egységre osztottuk a rétegsort. Az intervallum zónák alját minden esetben egy-egy marker faj elsố előfordulása (vélelmezett elsô megjelenése) jelöli ki. A Hemicytheria lorentheyi zóna a pannóniai rétegsor alsó 5,5 méterét fogja át. A Hemicytheria tenuistriata zóna 29 m, a Candona (Propontoniella) candeo zóna 18 m vastag. Az Amplocypris abscissa zóna mintázott vastagsága 6,5 méter. A hasonló fáciesú, bár homogénebb beocsini rétegsorban, amely a Fruska Gorában található mintegy 150 km-re délkeletre Pécstôl, magnetosztratigráfiai adatok alapján a szarmata-pannóniai határ kora 11,6 millió év, a Hemicytheria tenuistriata első megjelenésének kora 11,23 millió év, a Danitzpusztán az Amplocypris abscissa zónában megjelenő Candona (Reticulocandona) reticulata első előfordulásának kora pedig 10,2 millió év. Ezek alapján feltételezzük, hogy feltárásunkban a pannóniai márga rétegsor a 11,6 - 10 millió évek közti intervallumot képviseli.

A feltárás kagylósrák-és puhatestú zonációjának összevetése azt mutatja, hogy a Hemicytheria lorentheyi zóna egésze és a H. tenuistriata zóna legalsó része korrelálható a Lymnocardium praeponticum - Radix croatica zónával, míg a feltárás felső részén az Amplocypris abscissa zóna ad átfedést a Lymnocardium schedelianum zónával.

Keywords: késố Miocén, Pannon-tó, osztrakodák, öskörnyezet, biosztratigráfia, Mecsek

Abstract

The large outcrop at Pécs-Danitzpuszta, southern Hungary, exposes a 65-meter-thick succession of calcareous marls, clay marls and calcareous sands that were deposited during the early history of Lake Pannon, a vast, Caspian-type lake in Central Europe in the late Miocene. Within the framework of the complex stratigraphic investigation of this succession, well preserved, relatively diverse benthic ostracod assemblages containing 39 taxa were recovered from 29 samples (16 samples were barren). Palaeoecological interpretation of the ostracod genera suggests that deposition took place in a low-energy environment, in the shallow sublittoral zone of Lake Pannon, in pliohaline (9-16\% salinity) water. The entire succession was divided into four interval zones based on the first occurrences of assumedly useful marker fossils: Hemicytheria lorentheyi Zone (from sample D29), Hemicytheria tenuistriata Zone (from sample D17), Propontoniella candeo Zone (from sample D115) and Amplocypris abscissa Zone (from sample D209). Based on comparison to the Beočin section $150 \mathrm{~km}$ to the SE, where a lithologically and stratigraphically similar section was dated magnetostratigraphically by an international team, we tentatively assume that the Pannonian marl succession of the Pécs-Danitzpuszta outcrop represents the time interval of 11.6 to ca. $10 \mathrm{Ma}$. 


\section{Introduction}

In the large sand pit of Pécs-Danitzpuszta, which is famous for its unique middle to late Miocene reworked terrestrial and marine vertebrate remains (SZABÓ et al. this volume), a 65meter-thick, tectonically tilted succession is exposed that consists of calcareous marls, clay marls and calcareous sands (SEBE et al. 2021). This Pannonian (upper Miocene, Tortonian) succession represents fairly continuous sedimentation from the Sarmatian/Pannonian boundary to the top of the marl. The marl is overlain by a thick sand body that is exploited in the pit. This succession, deposited in Lake Pannon, offers a unique opportunity to investigate various fossil groups and to establish correlation between the biostratigraphic systems.

This study focuses on the ostracod fauna of the Pannonian marls. The primary objective of this work is the documentation of the ostracod assemblages along the profile in order to determine their biostratigraphic and palaeoecological significance. Early Pannonian ostracod records are poorly known in SW Hungary (SzÉLES 1982; SZUROMI-KoRECZ 1991, 1992), but they were extensively studied in other parts of the southern Pannonian Basin where the lithology and thus the inferred palaeoenvironment was similar to that in Danitzpuszta, such as the areas in the vicinity of Zagreb (SOKAČ 1972) and Belgrade (KRSTIĆ 1960, 1985; Rundić et al. 2011). Most recently, the ostracod record from the 120-meter-thick calcareous marl succession of Beočin (near Novi Sad, Serbia) was investigated and published by STOICA \& RUNDIĆ in TER BORGH et al. (2013). The Beočin outcrop was also subject to magnetostratigraphic investigations, which dated the marl succession between 11.6 Ma (Sarmatian/Pannonian boundary) and ca. 9.9 Ma (TER BORGH et al. 2013). These papers, as well as some other modern, well-documented ostracod studies on thoroughly investigated lower Pannonian outcrops from the entire area of Lake Pannon (e.g., Gross 2004, FiLIPESCU et al. 2011, OLTEANU 2011, BotKA et al. 2020) offer a good opportunity to place the Danitzpuszta ostracod record into a biostratigraphic and palaeoecological framework.

\section{Geological setting and stratigraphy}

The Pécs-Danitzpuszta sand pit is the best outcrop of the oldest Pannonian (upper Miocene) strata in the Mecsek area (KLEB 1973). The pit is located at the eastern boundary of Pécs, on the north side of Highway 6 (Figure 1). Sand has been produced here since the beginning of the $20^{\text {th }}$ century.

The stratigraphically lower part of the exposed Pannonian succession belongs to the Endrőd Formation (Figure 2; SEBE et al. 2015; SEBE et al. 2020). It consists of massive, greyish white calcareous marls, clay marls, sand, and even fine gravel, altogether amounting to 65 meters of stratigraphic thickness. The marls contain plant remains, a rich mollusk fauna and vertebrate fossils. Plant remains indicate a thermophilous flora with taxa suggesting extensive lakeshore swamp forests (HABly \& SEBE 2016). Based on the mollusk fauna, the bottom of the succession belongs to the
Lymnocardium praeponticum Zone, whereas the top of the marl is assigned into the Lymnocardium schedelianum Zone (11.6-11.4 Ma and 11-10.2 Ma respectively, according to MAgyar \& GeARY 2012, BotKa et al. 2021). The overlying limonitic, coarse-grained sands contain reworked middle Miocene (Badenian and Sarmatian) and Pannonian aquatic and terrestrial vertebrate fossils (KAZÁr et al. 2001, 2007; KAZÁR 2003; CSERPÁK 2018; SZABÓ et al. 2021), where the youngest terrestrial mammals, including the early form of Hippotherium primigenium, indicate the MN9/10 mammal zones (Vallesian, 11.1-8.7 Ma; Kordos in KAZÁR et al. 2001, 2007; KAZÁr 2003; GASPARIK in SebE et al. 2015).

The marl succession and partly the overlying sand and gravel beds were tilted into a near-vertical position by structural movements (KonRÁD \& SEBE 2010). We sampled the calcareous marl succession from two measured profiles. The upper part of the marl (D114 to D219) was sampled in 2015 in the eastern part of the northern wall of the sand pit, whereas the lower part (D35 to D1) was sampled in 2018, when a new trench was digged on the top of the northern wall across the almost vertical marl layers, exposing the oldest Pannonian, Sarmatian, and Badenian deposits (Figures 1, 2; SEBE et al. 2021).

\section{Material and methods}

Forty-five samples were examined from the 65-meter-thick Pannonian marl succession: 20 from its lower part, exposed in the trench at the northern wall of the pit, and 25 from the upper part of the succession, in the eastern part of the outcrop (Figure 1). Twenty-nine samples contained ostracod carapaces and single valves, the others were free of ostracods (Figure 3). The carbonate skeletal microfauna was processed with hydrogenperoxide (10\%) from about $500 \mathrm{~g}$ of air-dried sediments. The ostracod valves were selected under stereomicroscope. Hitachi S-2600N scanning electron microscope was used for SEM investigation. SEM images were taken at the Department of Botany of the Hungarian Natural History Museum in Budapest.

\section{Ostracod assemblages and palaeoenvironments}

The Danitzpuszta succession yielded a relatively diverse benthic ostracod material made up of 39 taxa with generally well-preserved valves (Appendix). Shed valves of juvenile specimens and valves of dead individuals can be preserved depending on delicacy of the valves and "valve-remains transport" (ZHAI et al. 2015).

$\rightarrow$ Figure 1. A) Lake Pannon within the Pannonian Basin at ca. 10.8 Ma (after MAGYAR et al. 1999). B) Aerial view of the Pécs-Danitzpuszta sand pit with the collection sites (C: pit, D: trench). C-D) Logged strata with the sample locations (C: pit, D: trench)

$\rightarrow$ 1. ábra. A)A Pannon-tó kiterjedése a Pannon-medencében kb. 10,8 millió évvel ezelött (MAGYAR et al. 1999 alapján). B) A pécs-danitzpusztai homokbánya a gyüjtési helyekkel (C: bányafal, D: kutatóárok). C-D) A bányafal (C) és a kutatóárok $(D)$ rétegsora a mintavételi helyekkel 

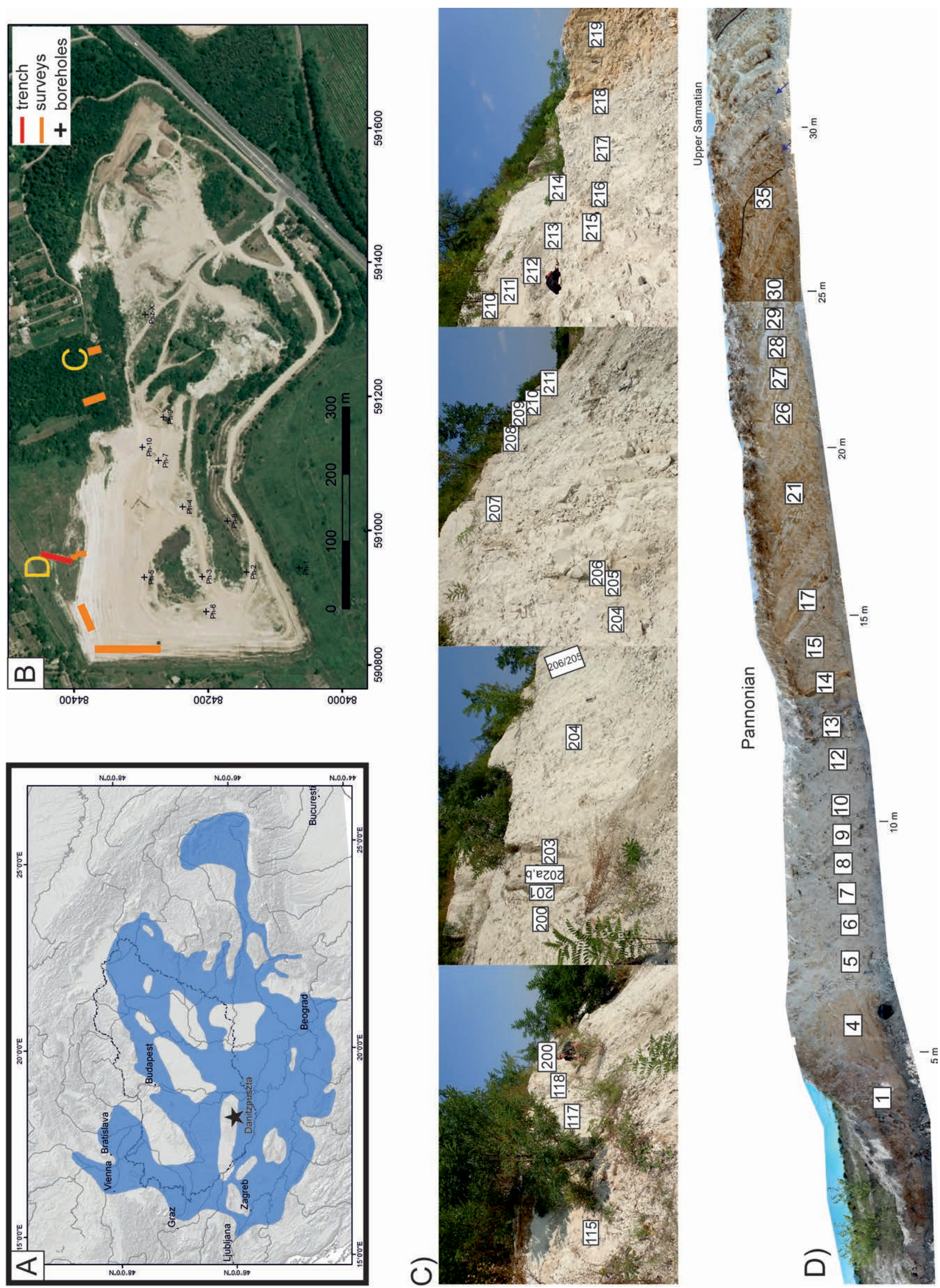

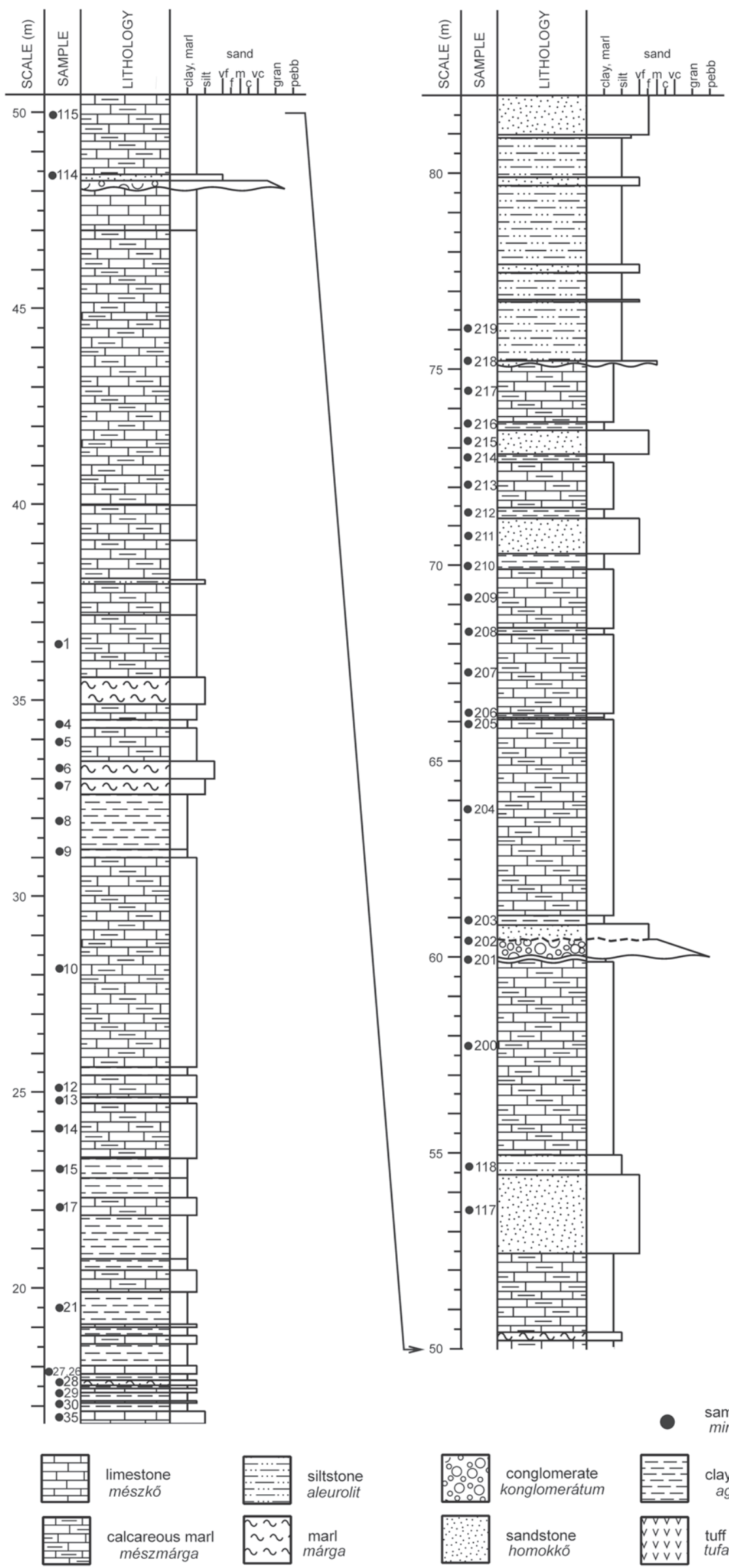

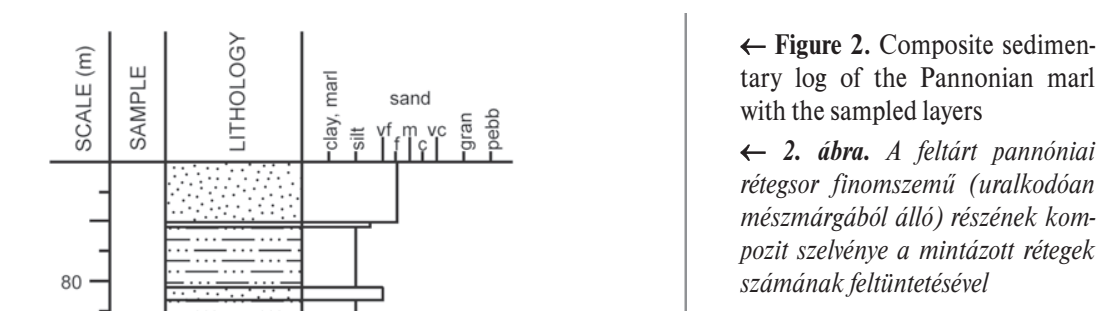

$\leftarrow$ Figure 2. Composite sedimentary $\log$ of the Pannonian marl számának feltüntetésével $\rightarrow$ Figure 3. Distribution of Pannonian ostracod species across the investigated succession. First occurences of biostratigraphic marker species (according to KRSTIĆ 1985) in black. The mollusk biozones are from ВоткA et al., 2021

$\rightarrow$ 3. ábra. A pannóniai kagylósrákok elöfordulása a vizsgált szelvényben. Azoknak a fajoknak az elsô elöfordulását, amelyeket KRSTIĆ (1985) biosztratigráfiai zónajelzöknek használt, fekete téglalapok jelzik. A puhatestü biozonációt BOTKA et al. (2021) alapján tüntettükfel 


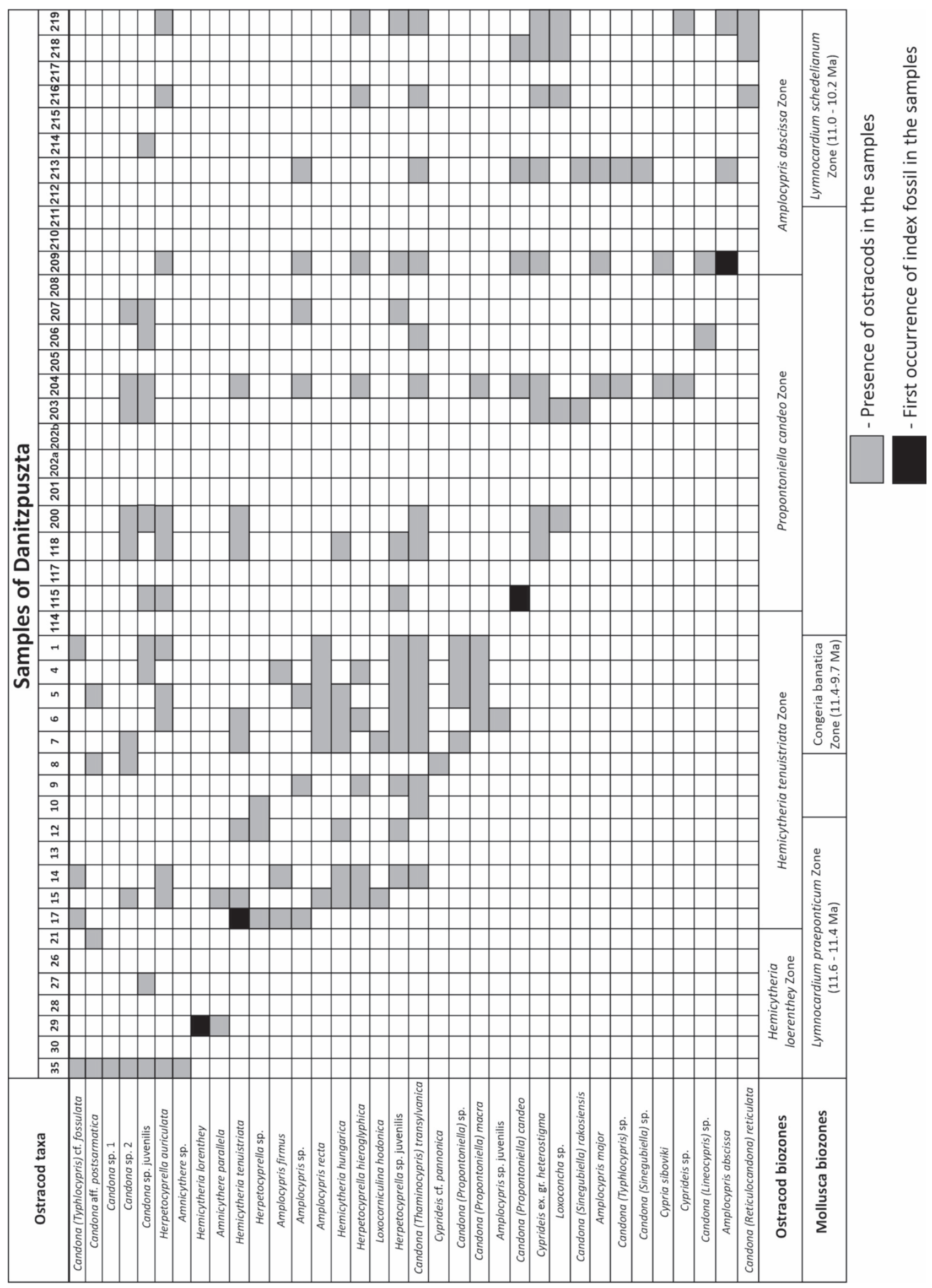


Sixteen samples were free of ostracods (Figure 3). No correlation was found between lithology and the barren samples; the presence or absence of benthic ostracods did not depend on the grain size of the sediments. Where ostracods were found, we did not see any indication of decreased oxygen levels. Changes in nutrient availability might have been a control on ostracod distribution, but this environmental factor is difficult to identify.

The composition of the ostracod fauna does not show any significant change across the section. Some of the identified genera (members of the Cytheroidea superfamily) are survivors of marine origin (Amnicythere, Loxoconcha, Loxocorniculina, Cyprideis, Hemicytheria), whereas others (members of the Cypridoidea superfamily) are considered freshwater and brackish immigrants ( $\mathrm{Cando}$ na, Cypria, Herpetocyprella, Amplocypris). In the following we briefly review the known habitat and (palaeo)ecological demand of each genus in order to create a basis for the environmental interpretation of our assemblages.

Amnicythere occurs in the lowermost part of the section (Figure 3). This genus appeared in the brackish marine Sarmatian and has radiated in the Paratethys. In addition to some sporadic occurrences in the Tortonian and lower Messinian of the Mediterranean, as many as 19 species were reported from the upper Messinian Lago-Mare deposits (GLIOZZI et al. 2005). The genus has 10 living representatives, all inhabiting fresh to oligo - mesohaline waters of the Black-Azov, Caspian and Aral Seas (Gliozzi \& Grossi 2008, NAміотко et al. 2011).

Representatives of genus Loxoconcha occur in the upper part of the section (Figure 3). This genus first appeared in the Cretaceous (MOORE 1961) or in the Palaeocene (Morkhoven 1963). According to Savatenalinton \& MARTENS (2009), family Loxoconchidae includes 22 extant genera, most of them living in marine and brackish environments; only six species are known from freshwater ecosystems (KARANOVIC 2012). In the modern ostracod fauna of the Caspian Sea, Loxoconcha is the most eurytopic genus, hence its high density on the shelf of the South Caspian basin (GOFMAN 1966). It can be equally found on algae, on the bottom, or within the substrate (ELOFSON 1941, PURI et al. 1969). Some species dwell in the profundal zone of the Caspian (down to $875 \mathrm{~m}$; BoOMER et al. 2005), but only a few species live in the agitated littoral zone with freshwater influence (GOFMAN 1966).

Loxocorniculina, an extinct genus of the family Loxoconchidae, was found in the lower part of the section (Figure 3). It is a typical Paratethyan form, which first appeared in the Sarmatian and spread into the Palaeo-Mediterranean during the late Messinian Lago-Mare event (FARANDA et al. 2007). The fossil Loxocorniculina djafarovi indicates oligohaline to mesohaline water of variable depth (IACCARINO et al. 2008).

Cyprideis occurs in the outcrop upsection from sample D8 (Figure 3). It first appeared at the end of the Palaeogene and spread across Eurasia and America in the Miocene. Its relatively few extant species can be found worldwide, especially in brackish and hypersaline (or otherwise chemically extreme), shallow-water environments (MORKHOVEN 1963, VAN HARTEN 1990). In the Caspian Sea, Cyprideis torosa was found in abundance in a sample from $13 \mathrm{~m}$ water depth, whereas it was completely missing from samples taken from $62 \mathrm{~m}$ depth and below (BOOMER et al. 2005). The phenotype (including size, shape, pores and ornaments of the valves) is influenced by environmental factors such as salinity (SANDBERG 1964; VAN HARTEN 1975, 2000; SCHWEITZER \& LOHMANN 1990; Bowles 2013). The widespread Cyprideis pannonica, occurring in sample D8, was observed to be characteristic for shallow, hypersaline or alkaline waters (BENSON 1973, 1978).

The extinct genus Hemicytheria, occurring throughout the outcrop (Figure 3), is mostly known from the Sarmatian and Pannonian layers of the Pannonian Basin System. It is interpreted to have lived in brackish (oligo- to pliohaline) waters, although less typically it has also been found in freshwater layers (SOKAČ 1972).

Of the genera that immigrated into Lake Pannon from freshwater and athalassic waterbodies, Candona is widespread throughout the outcrop (Figure 3). The nominal subgenus Candona is known to have populated freshwater lakes of the Northern Hemisphere since the Eocene (KRSTić 1972b), although a few species tolerate oligo- and miohaline environments as well. BoOMER et al. (2005) reported specimens from 62 to $405 \mathrm{~m}$ water depth from the Caspian. Most Candona (Candona) species are infaunal (MorKHOVEN 1963). Subgenus Propontoniella, a probable ancestor of subgenus Serbiella (KRSTić 1972b), is known exclusively from the older Pannonian deposits. The extant subgenus Lineocypris entered the palaeontological record in the Late Cretaceous. Today it lives in freshwater, especially in deep lakes (MorkHOVEn 1963). Subgenus Reticulocandona was originally endemic to Lake Pannon, but its fossils were recovered from the Pontian of Azerbaijan as well (KRSTIĆ 1972b). Subgenera Sinegubiella and Thaminocypris were endemic to Lake Pannon, although the latter was also found in the Mio-Pliocene of the Dacian basin. The first appearance of subgenus Typhlocypris was recorded in Lake Pannon. Its extant species are living in fresh- and athalassic waters of Europe (SOKAČ 1972).

The genus Cypria occurs in samples D204 and D209 (Figure 3). This genus is known from the Tertiary to the present day. Most of the extant species are active swimmers and prefer a freshwater, plant-rich environment (MORKHOVEN 1963; SOKAČ 1972). For instance, Cypria ophtalmica occurs in springs of five regions: Northern Italy, Eastern Iberia, Upper Danube, Southern Anatolia and Central and Western Europe (RosATI et al. 2014).

The species Herpetocyprella auriculata and $H$. hieroglyphica occur throughout the succession (Figure 3). The only extant Herpetocyprella species, $H$. mongolica lives in the saline lake of Issyk-Kul, Kyrgyzstan (KARANOvic 2012), while fossil species were reported from the freshwater Pliocene deposits of Central Asia (MANDELShTAM \& SHNEIDER 1963). Based on this distribution, DANIELOPOL et al. (2008) erected two hypotheses concerning the palaeo- 
ecology and palaeobiogeography of Herpetocyprella. According to the first hypothesis, it originally habitated shallow freshwaters, and its valves were transported into Lake Pannon. The second hypothesis claims that it was probably present in marginal environments of the Sarmatian Paratethys sea, and later it formed autochthonous populations in Lake Pannon. In the first case, adaptation of the originally freshwater genus to saline waters took place repeatedly and independently in Central Europe and later in Central Asia, whereas in the latter case a salt-tolerating species migrated from Lake Pannon to Central Asia in a stepping-stone manner, from lake to lake (DANIELOPOL et al. 2008). We think that the common occurrence and wide geographical distribution of Herpetocyprella in Lake Pannon deposits (see above), with our Danitzpuszta data added, favors the second model. RunDIĆ (2006) found that Herpetocyprella species ("Hungarocypris" in that paper) were typical nearshore dwellers, preferring sandy substrates, and that they rarely occur in fine-grained sediments. In our material, however, both Herpetocyprella species were found in offshore clays and silts, similarly to the Transylvanian Basin samples of Kovécs et al. (2016) and BotKA et al. (2020), and to the Kisalföld ("Danube") Basin samples of CZICZER et al. (2009). Herpetocyprella auriculata and $H$. hieroglyphica thus appear to have been rather ubiquitous species that inhabited the littoral to sublittoral and perhaps even the profundal zones of the early Lake Pannon.

The extinct genus Amplocypris, occurring throughout the section (Figure 3), is represented by at least four species in the outcrop. This genus was apparently endemic to Lake Pannon and later migrated to the Dacian Basin.

Based on the modern distribution and environmental demand of Loxoconcha, Cyprideis and Amnicythere, the investigated assemblages probably lived in relatively shallow but low-energy, pliohaline (9-16\%o salinity) waters in the sublittoral zone of Lake Pannon. Various subgenera of Candona obviously tolerated brackish water, as it is evidenced by the extant Typhlocypris. Probably the same applies to the few Cypria species that are widespread in the deposits of Lake Pannon. Herpetocyprella seems to have been a highly eurytopic genus. The other extinct genera, i.e., Loxocorniculina, Hemicytheria and Amplocypris were all brackish-water (oligo- to pliohaline) dwellers.

\section{Biostratigraphy}

Pannonian ostracod biostratigraphic systems are numerous (e.g. SOKAČ 1972, 1990; JIŘIČEK 1983, 1985; KRSTIĆ 1974, 1985, 1990; Szuromi-KoreCz 1992; Figure 4). The most detailed, highest-resolution system was elaborated by KRSTIĆ $(1985,1990)$, based primarily on densely collected samples from outcrops in the area of the former Yugoslavia. Recently, however, several authors emphasized that the influence of the palaeoenvironmental changes on the distribution of ostracods had been underestimated, and that a reconsideration of the biozonation is needed (e.g., Gross 2004, Olteanu 2011, Stoica \& Rundić in Ter Borgh et al. 2013).

Keeping the difficulties and uncertainties of Pannonian ostracod biostratigraphy in mind, we based the evaluation of the Danitzpuszta material on the stratigraphic system of KRSTIĆ (1985). However, instead of her rather vaguely defined zones, we looked for first occurrences of species, and defined our zones as interval zones between those first occurrences. We also compared our results with the ostracod record from Beočin in Serbia (STOICA \& RUNDić in TER BorGH et al. 2013), where the lithology of the investigated succession and thus the inferred depositional environment is similar to that of Danitzpuszta, and where the first occurrences of ostracod species had been dated by magnetostratigraphic method (TER BORGH et al. 2013). (The correlation between the micropalaeontologically and the magnetostratigraphically investigated sections of the Beočin outcrop is missing from TER BORGH et al. 2013, but is available in the PhD thesis of TER BORGH 2013). We are confident that the relatively uniform lithology and depositional environment throughout the section lends credit to our biostratigraphic evaluation.

Based on consecutive first occurrences, we distinguished four stratigraphic intervals (interval zones) in the Danitzpuszta succession: Hemicytheria lorentheyi Zone (D35 to D21), Hemicytheria tenuistriata Zone (D17 to D114), Propontoniella candeo Zone (D115 to D208), and Amplocypris abscissa Zone (D209 to D219) (Figure 3).

Hemicytheria lorentheyi occurs in only one sample (D29), but this species is known to be characteristic of the lowermost Pannonian interval in other sections (e.g., MÉHES 1908, GROSS 2004). Other species occurring in the Hemicytheria lorentheyi Zone in our material include Amnicythere parallela, Amnicythere sp., Herpetocyprella auriculata, Candona (Typhlocypris) cf. fossulata and C. aff. postsarmatica (Figure 3). Candona postsarmatica is also considered a very basal Pannonian species, a contemporary of Hemicytheria lorentheyi; SzUROMI-KORECZ (1992) identified it in the Nagykozár-2 borehole, $4 \mathrm{~km} \mathrm{~S}$ of the Danitzpuszta outcrop, where it occurred in the lowermost Pannonian Spiniferites pannonicus Zone of the dinoflagellate biostratigraphy (SÜTŐNÉ SZENTAI 2012).

Hemicytheria tenuistriata first occurs in sample D17 (Figure 3). The stratigraphic range of this species is known to overlap with that of Hemicytheria lorentheyi, but it has not been reported so far from the lowermost Pannonian layers. In Beočin, $H$. tenuistriata first occurs in a reversed polarity interval, interpreted to be between C5r1n and C5r.2r-1n, and thus dated at $11.23 \mathrm{Ma}$ (inferred by us from data available in TER BORGH 2013). The Hemicytheria tenuistriata Zone in Danitzpuszta contains the following species: Amplocypris firmus, A. recta, Amplocypris sp., Candona (Thaminocypris) transylvanica, C. (Typhlocypris) cf. fossulata, C. (Propontoniella) macra, C. (Propontoniella) sp., C. aff. postsarmatica, Candona sp., Cyprideis cf. pannonica, Hemicytheria hungarica, Herpetocyprella 


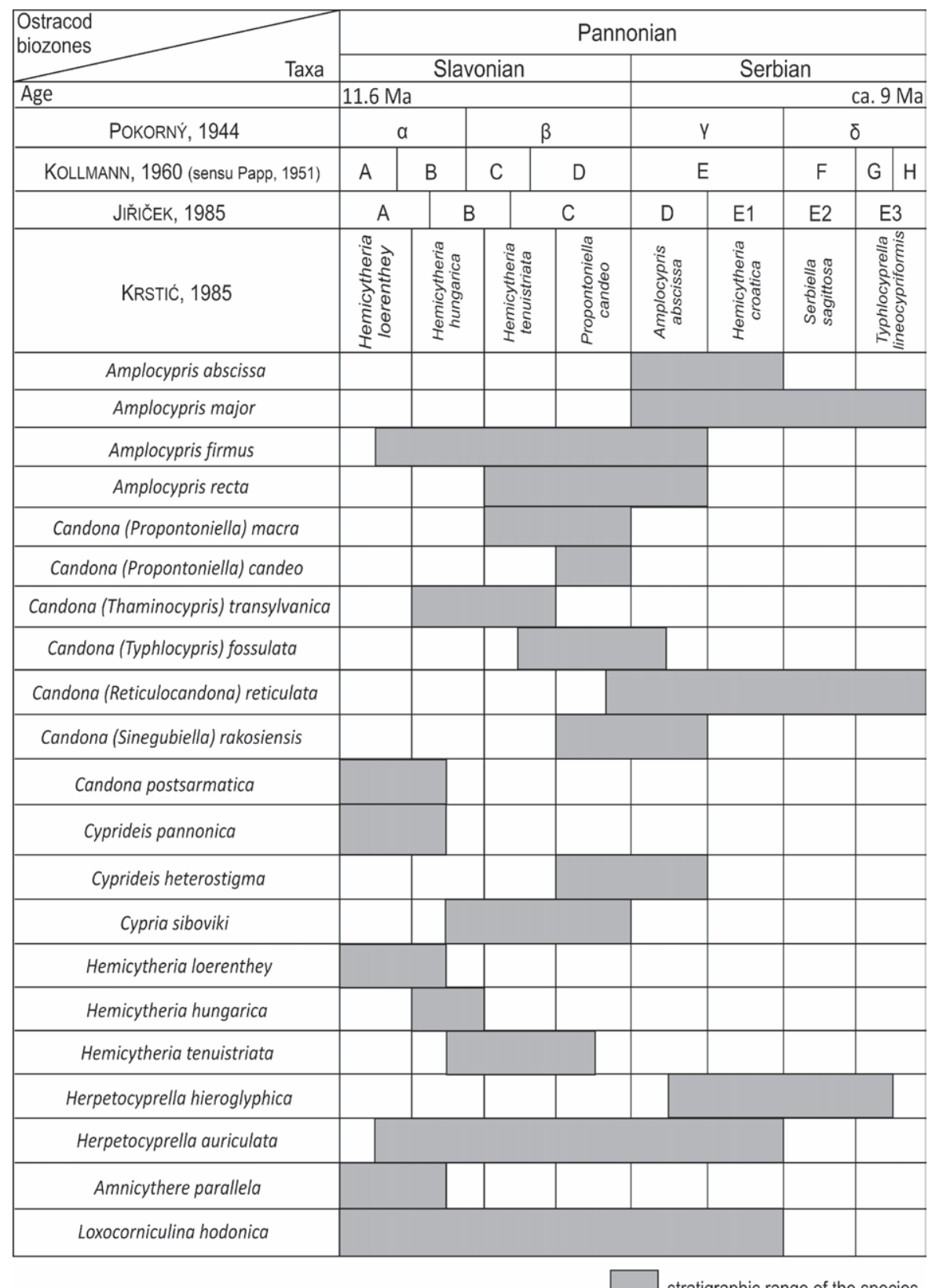

Figure 4. Literature-based stratigraphic distribution of the ostracod species identified in the Pécs-Danitzpuszta outcrop, according to PoKORNY (1944), KolLMANN (1960), JIŘIĆEK (1985) and KRSTIĆ (1985). Compilation is based on KovÁcs et al. (2016)

4. ábra. A pécs-danitzpusztai feltárásban azonositott pannóniai kagylósrák fajok rétegtani elterjedése POKORNÝ (1944), KolLMANN (1960), JIŘIČEK (1985) és KRSTIĆ (1985) alapján. A korreláció KoVíCS et al. (2016) munkáját követi

hieroglyphica, H. auriculata, Herpetocyprella sp., Amnicythere parallela and Loxocorniculina hodonica (Figure 3). Amplocypris firmus and Loxocorniculina hodonica share their first occurrence with Hemicytheria tenuistriata both in the Danitzpuszta and Beočin records.

Candona (Propontoniella) candeo first occurs in sample D115 (Figure 3). This species is missing from the Beočin record, but it was recorded in the stratigraphically thoroughly investigated succession of Guşterița (Sibiu, Transylvanian Basin, Romania; BotKA et al. 2020). In that outcrop, the first occurrence of Candona (Propontoniella) candeo was coeval with the first occurrence of the dinoflagellate species Pontiadinium pecsvaradense, and the age of their first occurrence was speculated to be about $10.75 \mathrm{Ma}$. In the Danitzpuszta outcrop, however, an occurrence of Pontiadinium pecsvaradense is known from D1-3 (KRIZMANIĆ et al., 2021), 14-15 m below the first occurrence of Candona (Propontoniella) candeo in sample D115. (In fact, specimens of subgenus Propontoniella from samples D1, D4, D5 and D7 might belong to Candona (Propontoniella) candeo, but their poor preservation hindered species-level identification.) The following species occur in our Candona 
(Propontoniella) candeo Zone: Candona (Propontoniella) macra, C. (Sinegubiella) rakosiensis, C. (Thaminocypris) transylvanica, C. (Typhlocypris) sp., Cypria siboviki, Cyprideis ex. gr. heterostigma, Hemicytheria tenuistriata, $\mathrm{H}$. hungarica, Herpetocyprella auriculata, and $H$. hieroglyphica (Figure 3).

Amplocypris abscissa first occurs in sample D209 (Figure 3). This species was not recorded in Beočin (although a taxonomically questionable form designated „Amplocypris ex gr. abscissa" is present throughout the section, from the Sarmatian/Pannonian boundary up to the highest sample, covering the time interval of 11.6-9.9 Ma; TER BORGH et al. 2013). Other species in our Amplocypris abscissa Zone include Amplocypris major, Candona (Propontoniella) candeo, C. (Reticulocandona) reticulata, C. (Sinegubiella) rakosiensis, C. (Thaminocypris) transylvanica, Cypria siboviki, Cyprideis ex. gr. heterostigma, Herpetocyprella auriculata, H. hieroglyphica (Figure 3). Candona (Reticulocandona) reticulata, first occurring in sample D216, is one of the latest appearing species in the Beočin section as well; its first occurrence corresponds to ca. 10.25 Ma (assuming a constant depositional rate throughout $\mathrm{C} 5 \mathrm{n} .2 \mathrm{n}$ in the Beočin succession).

Comparing the ostracod and mollusk zonations in the Danitzpuszta outcrop, we found that the Hemicytheria lorentheyi Zone and the lowermost part of the Hemicytheria tenuistriata Zone overlap with the Lymnocardium praeponticum-Radix croatica Zone. In the upper part of the section, the Amplocypris abscissa Zone overlaps with the Lymnocardium schedelianum Zone. This latter relationship is similar to that reported from the Hennersdorf section (cf., HARZHAUSER \& MANDiC 2004 and DANIElopol et al. 2011).

\section{Conclusions}

The Pécs-Danitzpuszta outcrop yielded a characteristic limno-brackish Lake Pannon benthic ostracod fauna with well-preserved valves from 29 samples collected from the 65 meter thick Pannonian Endrôd Marl succession. Thirtynine ostracod taxa, which belong to 9 genera, 8 families and 1 order (Podocopida), were identified.

Based on the ecology of extant genera and palaeoecological interpretation of the extinct ones, the studied ostracod assemblages probably lived in relatively shallow but low-energy, pliohaline (9-16\%o salinity) waters in the sublittoral zone of Lake Pannon.

Biostratigraphically, we divided the succession into four interval zones based on the first occurrence (supposed first appearance) of four species. The Hemicytheria lorentheyi Zone is $5.5 \mathrm{~m}$ thick, and represents the basal part of the Pannonian succession (from 11.6 Ma onwards). The overlying Hemicytheria tenuistriata Zone is $29 \mathrm{~m}$ thick; the first occurrence of $H$. tenuistriata in the Beočin outcrop was magnetostratigraphically dated as $11.23 \mathrm{Ma}$. The following Candona (Propontoniella) candeo Zone is $18 \mathrm{~m}$ thick. The overlying Amplocypris abscissa Zone was sampled in $6.5 \mathrm{~m}$ thickness. Because Candona (Reticulocandona) reticulata, first appearing in the Beočin succession at ca. 10.2 Ma, has its first occurrence in the upper part of this $6.5 \mathrm{~m}$ interval, we tentatively suggest that the age of the investigated Pannonian interval is $11.6-10 \mathrm{Ma}$.

\section{Acknowledgements}

Radovan PIPÍK and Péter OzSVÁRT are thanked for their careful reviews. The palaeontological investigations were partly supported by the Hantken Foundation and the project EFOP 3.6.1-16-2016-00004 at the University of Pécs. The research was financially supported by the Hungarian National Research, Development and Innovation Office NKFIH No. 116618. The authors would like to dedicate this study to Dr Nadežda Krstić, the outstanding micropalaeontologist and expert of Pannonian ostracods. This is MTAMTM-ELTE Paleo contribution No 352.

\section{References-Irodalom}

Bassiouni, M. A. 1979: Brakische und marine Ostrakoden (Cytherideinae, Hemicytherinae, Trachyleberidinae) aus dem Oligozän und Neogen der Türkei. - Geologisches Jahrbuch, B 31, 1-200.

Beker, K., TunoĞLu, C. \& Ertekin, İ. K. 2008: Pliocene-Lower Pleistocene Ostracoda Fauna from Insuyu Limestone (KarapınarKonya/Central Turkey) and its Paleoenvironmental Implications. - Türkiye Jeoloji Bülteni 51/1, 1-32.

BENSON, R. H. 1973: 36.2 Psychrospheric and continental ostracoda from ancient sediments in the floor of the Mediterranean. - In: RYAN, W. B. F. \& Hsü, K. J. (eds): Initial Reports of the Deep Sea Drilling Project 13, 1002-1008.

Benson, R. H. 1978: 35. The Paleoecology of the ostracodes of DSDP LEG 42A. - Deep Sea Drilling Project Initial Reports 42, $777-787$.

Boomer, I., Grafenstein, U., Guichard, F. \& BiedA, S. 2005: Modern and Holocene sublittoral ostracod assemblages (Crustacea) from the Caspian Sea: A unique brackish, deep-water environment. - Palaeogeography, Palaeoclimatology, Palaeoecology 225, $173-186$. https://doi.org/10.1016/j.palaeo.2004.10.023

Botka, D., Magyar, I., Csoma, V., Tóth, E., Šujan, M., Ruszkiczay-Rüdiger, Zs., Chyba, A., Braucher, R., SANt, K., Ćorić, S., Baranyi, V., BaKraČ, K., Krizmanić, K., Bartha, I. R., Szabó, M. \& Silye, L. 2020: Integrated stratigraphy of the Guşterița clay pit: a key section for the early Pannonian (late Miocene) of the Transylvanian Basin (Romania). - Austrian Journal of Earth Sciences, 112/2, 221-247. https://doi.org/10.17738/ajes.2019.0013. 
Botka, D., Rofrics, N., Katona, L. \& Magyar, I. 2021: Pannonian and Sarmatian mollusks from Pécs-Danitzpuszta, southern Hungary: a unique local faunal succession. - Földtani Közlöny 151/4, 335-362.

Bowles, R. E. 2013: The use of the ostracode Cyprideis Americana (Sharpe) as a proxy for salinity in Bahamian Lake systems. - Master Thesis and Specialist Projects, 1-56.

Carbonnel, G. 1978: L'espéce Cyprideis pannonica Mehes, 1908 dans la Téthys au Messinien (Miocéne). - Documents des Laboratoires de Géologie de la Facultés de Sciences de Lyon 72, $79-97$.

CERnAJSEK, T. 1974: Die Ostracodenfaunen der Sarmatischen Schichten in Österreich. - In: BrESTENSKÁ, E. (ed.): Chronostratigraphie und Neostratotypen Miozän der Zentralen Paratethys IV, 458-491.

Chintauan, I. 2000: Ostracode din volhynianul de la livezile Bistrita-Nasaud. - Studii si cercetari (Geologie-Geografie). Bistrita 5, 57-61.

Chintauan, I. \& Nicoroci, E. 1976: Ostracodele miocene din sudul bazinului Şimleu. Dări de seamă ale şedințelor, - Institutul de Geologie şi Geofizică, 3. Paleontologie (1974/75) 62, 3-23.

CZiczer, I., Magyar, I., Pipíx, R., Böhme, M., Ćorić, S., BAKraČ, K. \& Müller, P. 2009: Life in the sublittoral zone of long-lived Lake Pannon: paleontological analysis of the Upper Miocene Szák Formation, Hungary. - International Journal of Earth Sciences 98/7, 1741-1766. https://doi.org/10.1007/s00531-008-0322-3.

CSERPÁK F. 2018: Középső-miocén sziláscet (Cetacea: Mysticeti) humerusok a Pécs, danitzpusztai homokbányából. - Földtani Közlöny 148/3, 255-255. https://doi.org/10.23928/foldt.kozl.2018.148.3.255.

Danielopol, D. L., Buttinger, R., Pipík, R., Gross, M., Olteanu, R. \& Knoblechner, J. 2008: Miocene „Hungarocypris” species of Lake Pannon (Central and South-Eastern Europe) transferred to Herpetocyprella DADAY, 1909 (Ostracoda, Cyprididae). Senckenbergiana lethaea $\mathbf{8 8 ,}$, 147-160.

Danielopol, D. L., Gross, M., Harzhauser, M., Minati, K. \& Piller, W. E. 2011: How and why to achieve greater objectivity in taxonomy, exemplified by a fossil ostracod (Amplocypris abscissa) from the Miocene Lake Pannon. - Joannea Geologie und Paläontologie 11, 273-326.

DoRnič, J. \& KHEIL, J. 1963: Ein Beitrag zur Mikrobiostratigraphie und Tektonik der NW-Randteile des Wiener Beckens und des sog. Uherské Hradiště-Grabens. Sbornik Geologickych Věd. - Geologie 3, 85-107.

ELOFSON, O. 1941:Zur kenntnis der marinen ostracoden Schwedens mit besonderer berucksichtigung des Skageraks. - Zoologiska bidrag fran Uppsala, 19, 217-534.

FARAnda, C., Gliozzi, E. \& Ligios, S. 2007: Late Miocene brackish Loxoconchidae (Crustacea, Ostracoda) from Italy. - Geobios 40/3, 303324. https://doi.org/10.1016/j.geobios.2006.11.001

Filipescu, S., WaneK, F., Miclea, A., De Leeuw, A. \& Vasiliev, I. 2011: Micropaleontological response to the changing paleoenvironment across the Sarmatian-Pannonian boundary in the Transylvanian Basin (Miocene, Oarba de Mureş section, Romania). - Geologica Carpathica 62/1, 91-102. https://doi.org/10.2478/v10096-011-0008-9.

FreEls, D., 1980: Limnische Ostracoden aus Jungtertiaer und Quaterner Türkei. - Geologisches Jahrbuch, B 39, 1-172.

Gliozzi, E. \& Grossi, F. 2008: Late messinian lago-mare ostracod palaeoecology: A correspondence analysis approach. - Palaeogeography Palaeoclimatology Palaeoecology 264, 288-295. https://doi.org/10.1016/j.palaeo.2007.03.055

Gliozzi, E., Rodriguez-Lazaro, J., Nachite, D., Martin-Rubio, M. \& BeKkali, R. 2005: An overview of Neogene brackish leptocytherids form Italy and Spain: Biochronological and palaeogeographical implications. - Palaeogeography, Palaeoclimatology, Palaeoecology 225, 283-301. https://doi.org/10.1016/j.palaeo.2005.06.015

GofmAn, E. A. 1966: Ecology of modern and Novocaspian ostracods of the Caspian Sea. - Akademie NAUK, SSSR, Moscow, 183 p.

GramanN, F. 1969: Das Neogen im Strimon Becken (Griechisch Ostmazedonien). Teil: II Ostracoden und Foraminiferen aus dem Neogen des Strimon Beckens. - Geologisches Jahrbuch 87, 485-528.

Grekoff, N. \& Molinari, V. 1963: Sur une faune d'Ostracodes saumâtres du Néogene de Castell'Arquato (Emilia). - Geologica Romana 2, 1-6.

Gross, M. 2004: Contribution to the ostracode fauna (Crustacea), paleoecology and stratigraphy of the clay pit Mataschen (Lower Pannonian, Styrian Basin, Austria). - Joannea Geologie und Paläontologie 5, 49-129.

HABLY, L. \& SEBE, K. 2016: A late Miocene thermophilous flora from Pécs-Danitzpuszta, Mecsek Mts., Hungary. - Neues Jahrbuch für Geologie und Paläontologie, Abhandlungen 279/3, 261-272. https://doi.org/10.1127/njgpa/2016/0554.

Hanganu, E. 1966: Etude stratigraphique du Pliocène situé entre les vallées de Teleajen et de Prahova. - Comitetul de Stat al Geologiei, Institutul Geologic, Studii Tehnice şi Economice, Seria J, Stratigrafie 2, 1-127.

Hartmann, G. \& PURI, H. S. 1974: Summary of neontological and paleontological classification of Ostracoda. - Mitteilungen aus dem hamburgischen zoologischen Museum und Institut 70, 7-73.

HARZHAuser, M. \& MANDiC, O. 2004: The muddy bottom of Lake Pannon - a challenge for dreissenid settlement (Late Miocene; Bivalvia). - Palaeogeography, Palaeoclimatology, Palaeoecology, 204/3-4, 331-352. https://doi.org/10.1016/S0031-0182(03)00735-1.

HÉJJAS I. 1894: Új adatok Erdély fossil ostracoda-faunájához. [New data for the fossil ostracod fauna of Transylvania]. - Értesító az. Erdélyi Múzeum-Egylet Orvos-természettudományi Szakosztályából, II. Természettudományi Szak 16, 35-68. (in Hungarian)

Horne, D. J., Cohen, A. \& Martens, K. 2002. Taxonomy, morphology and biology of Quaternary and living Ostracoda. - The Ostracoda: applications in Quaternary research, 131, 5-36. https://doi.org/10.1029/131GM02

iaccarino, S. M., Bertini, A., Di Stefano, A., Ferraro, L., Gennari, R., Grossi, F., Lirer, F., Manzi, V., Menichetti, E., Lucchi, M., R., Taviani, M., Sturiale, G. \& Angeletti, L. 2008: The Trave section (Monte dei Corvi, Ancona, Central Italy): an integrated paleontological study of the Messinian deposits. - Stratigraphy 5/3-4, 281-306.

IONESI, B. \& CHINTAUAN, I. 1972: Studiul ostracodelor din depozitele bugloviene de pe platforma moldovenească. - Dări de seamă ale şedințelor, Stratigrafie 60, 89-113. 
IONESI, B. \& ChINTAUAN, I. 1975: Studiul ostracodelor din depositele Volhiniene de pe Platforma Moldovenească (sectorul dintre valea siretului şi valea Moldovei). - Dări de seamă ale şedințelor, Stratigrafie (1973-1974) 61, 3-14.

IONESI, B. \& ChINTAUAN, I. 1980: Contributii la cunoaşterea faunei de ostracode din Basarabianul Platformei a Moldovaneşti (Regiunea dintre Siret si Moldova). - Annals of Alexandru Ioan Cuza University of Iaşi 26/2b, 59-66.

IONESI, B. \& ChintAuAn, I. 1985: Ostracofaune des dépôts Besarabiens de la région Văleni (Dobrogea du sud). - Annals of Alexandru Ioan Cuza University of Iaşi. Geology, Geography 31/2b, 32-36.

IONESI, B. \& ChINTAUAN, I. 1986: Contributions à la connaissance d'ostracofaune du Volhynien (Dobrogea du sud). - Anuarul Muzeului de Stiinte Natural Piatra Neamt Geologie-Geografie 5 (1980-1982), 83-91.

JIŘíčEK, R. 1983: Redefinition of the Oligocene and Neogene ostracod zonation of the Paratethys. - Knihovnička Zemního plynu a nafty 4, 195-236.

JIǨíČEK, R. 1985: Die Ostracoden des Pannonien. - In: PAPP, A. (ed.): Chronostratigraphie und Neostratotypen, Miozän der Zentralen Paratethys 7, Pannonien, Akadémia Kiadó, Budapest, 378-425.

KARANOVIC, I. 2012: Recent freshwater ostracods of the world. Crustacea, Ostracoda, Podocopida. - Springer-Verlag Berlin Heidelberg, 607 p. https://doi.org/10.1007/978-3-642-21810-1

KAZÁR E. 2003: Miocén fogascet-leletek (Cetacea: Odontoceti) a Kárpát-medencében. [Miocene toothed whales (Cetacea: Odontoceti) in the Carpathian Basin.] - PhD thesis, 344, Eötvös Loránd University, Budapest. (in Hungarian)

KAZÁR E., Kordos L. \& SzónOKY M. 2001: Danitz-pusztai homokbánya. Pannon homok áthalmozott ősgerinces-maradványokkal. Excursion Guide, 4. Magyar Ôslénytani Vándorgyúlés, Pécsvárad: Budapest, Magyarhoni Földtani Társulat Ôslénytani-Rétegtani Szakosztály, 42-43.

KazÁr E., Kordos L. \& SzÓNoky M. 2007: Danitz-puszta. - In: PÁlfy J. \& PAZONYI P. (eds): Óslénytani kirándulások Magyarországon és Erdélyben. Hantken Kiadó, Budapest, 131-132.

KLEB B. 1973: A mecseki pannon földtana. - A Magyar Állami Földtani Intézet Évkönyve 53/3, 750-943.

Kollmann, K. 1960: Cytherideinae und Schulerideinae n. subfam. (Ostracoda) aus dem Neogen des östlichen Österreich. - Mitteilungen der Österreichischen Geologischen Gesellschaft 51, 28-195.

KonRÁD Gy. \& SEBE K. 2010: Fiatal tektonikai jelenségek új észlelései a Nyugati-Mecsekben és környezetében. - Földtani Közlöny 140/2, 445-468.

Kováč, M., Baráth, I., KovÁčovÁ-Slamková, M., Pipík, R., HlavatÝ, I. \& HudáčKovÁ, N. 1998: Late Miocene paleoenvironments and sequence stratigraphy: northern Vienna Basin. - Geologica Carpathica 49/6, 445-458.

Kovács Á., Sebe K., Magyar I., Szuromi-Korecz A. \& Kovács E. 2019: Pannóniai üledékképződés és szerkezeti mozgások az Északi-pikkely (Kelet-Mecsek) területén. - Földtani Közlöny 148/4, 327-340. https://doi.org/10.23928/foldt.kozl. 2018.148.4.327

Kovács, E., Magyar, I., Sztanó, O. \& Pipík, R. 2016: Pannonian ostracods from the southwestern Transylvanian basin. - Geologia Croatica 69/2, 213-229. https://doi.org/10.4154/GC.2016.16.

Krizmanić, K., Sebe, K. \& Magyar, I. 2021: Dinoflagellate cysts from the Pannonian (late Miocene) "white marls" in PécsDanitzpuszta, southern Hungary. - Földtani Közlöny 151/3, 267-274.

KRSTIĆ, N. 1960: Beitrag zur Kenntnis der pannonischen Ostracoden in der Umgebung von Beograd. - Annales Géologiques de la Péninsule Balkanique 27, 269-284.

KRStić, N. 1968a: Ostracodes des couches congeriennes: 1. Cyprideis I. - Bulletin du Museum d'histoire naturelle de Belgrade, Series A 23, 107-151.

KRSTIĆ, N. 1968b: Pontian Ostracods from Eatern Serbia: Candona and Cypria. - Vesnik Zavoda za Geološka i Geofizička Istraživanja, Series A 26, 243-251.

KrStić, N. 1972a: Ostrakodi kongeriskih slojeva: 10. Loxoconcha. - Bulletin du Museum d'histoire naturelle de Belgrade, Series A, 27, $243-275$.

Krstić, N. 1972b: Genus Candona (Ostracoda) from Congeria Beds of Southern Pannonian Basin. - The Serbian Academy of Sciences and Arts, Monographs 450/39, 1-145.

KRSTIĆ, N. 1973a: Ostracodes of the Congeria beds: 11. Amnicythere. - Radovi Instituza geološko-rudarska istraživanja ispitivanja nuklearnih i drugih mineralnih sirovina 8, 53-99.

Krstić, N. 1973b: Plocenski Ostrakodi Metohije, 1. - Bulletin du Museum d'histoire naturelle de Belgrade 28, $151-173$.

KRSTIĆ, N. 1973c: Biostratigraphy of the congerian beds in the Belgrade region on the basis of Ostracoda with the description of the species of the genus Amplocypris. - Institute for Geological and Mining Explorations and Investigation of Nuclear and Other Mineral Raw Materias, Monographs 4, 208.

KRSTIĆ, N. 1974: Biostratigraphy of the Pannonian and Pontian stages in the South-eastern part of the Pannonian Basin based upon the ostracodan fauna. - Memoire BRGM 78, 459-467

KRSTIĆ, N. 1975: Ostracods of the congerian beds: Species of the genus Cypria and some other insufficiently defined forms. - Radovi Geoinstituta 10, 195-206.

KrSTIĆ, N. 1980a: Nove vrste ostakoda sa parastratotipova Panona. - Radovi Geoinstituta 14, 147-158.

KRSTIĆ, N. 1980b: Some Miocene ostracods Aleksinac's Pomoravlje. Rad. - Radovi Geoinstituta 14, 116-124.

KRSTIĆ, N. 1985: Ostracoden im Pannonien der Umgebung von Belgrad. - In: PAPP, A. (ed.): Chronostratigraphie und Neostratotypen, Miozän der Zentralen Paratethys 7, Pannonien, Akadémia Kiadó, Budapest, 103-143.

KRSTIĆ, N. 1990: Contribution by ostracods to the definition of the boundaries of the Pontian in the Pannonian Basin. - In: STEVANOVIĆ, P. M., Nevesskaja, L. A., Marinescu, F., SoKaČ, A. \& JÁmbor, Á. (eds): Chronostratigraphie und Neostratotypen. Neogen der Westlichen ('Zentrale') Paratethys 8, Pl1, Pontien 45-7. 
KrStić, N. \& StANCHEVA, N. 1990: Ostracods of Eastern Serbia and Northern Bulgaria with notice on a Northern Turkey assemblage. In: Stevanović, P. M., Nevesskaja, L. A., Marinescu, F., Sokač, A. \& JÁmbor, Á. (eds): Chronostratigraphie und Neostratotypen. Neogen der Westlichen ('Zentrale') Paratethys 8, Pl1, Pontien, 753-819.

Lorenschat, J., Pérez, L., Correa-Metrio, A., Brenner, M., Von Bramann, U. \& Schwalb, A. 2014: Diversity and spatial distribution of extant freshwater ostracodes (Crustacea) in ancient Lake Ohrid (Macedonia/Albania). - Diversity 6/3, 524-550. https://doi.org/ $10.3390 / \mathrm{d} 6030524$.

MAGYAR, I. \& GEARY, D., H. 2012: Biostratigraphy in a late Neogene Caspian-type lacustrine basin: Lake Pannon, Hungary. In: BaGANZ, O., W., BARTOV, Y., BoHACs, K. \& NumMEDAL, D. (eds): Lacustrine sandstone reservoirs and hydrocarbon systems. - AAPG Memoir, 95, 255-264. https://doi.org/10.1016/S0031-0182(98)00155-2

Mandelstam, M. I. \& SchneIDER, G. F. 1963: Iskopaemye ostrakody SSSR. Semejstvo Cyprididae. - Trudy Vsesoyusnogo NauchnoIssledovatelskogo Geologo-Razvedochnogo Neftyanogo Instituta (VNIGRI) 203, 1-332.

Mazzini, I., HudáčKová, N., Joniak, P., Kováčová, M., Mikes, T., Mulch, A., Rojay, F., Lucifora, S., Esu, D. \& Soulié-Märsche, I. 2013: Palaeoenvironmental and chronological constraints on the Tuğlu Formation (Çankırı Basin, Central Anatolia, Turkey). Turkish Journal of Earth Sciences 22/5, 747-777. https://doi.org/10.3906/yer-1207-10

MÉHEs Gy. 1907: Adatok Magyarország pliocén Ostracodáinak ismeretéhez I. - Földtani Közlöny 37, 429-467.

MéHEs Gy. 1908: Adatok Magyarország pliocén Ostracodáinak ismeretéhez II. Az alsópannóniai emelet Darwinulidae-i és Cytheridae-i. Földtani Közlöny 38, 537-568.

Moore, R., C. 1961: Treatise on Invertebrate Paleontology, Q Arthropoda. 3. Ostracoda - Geological Society of America University Kansas, 442 p.

Morkhoven, F. P. C., M. 1963: Post-Palaeozoic Ostracoda. - Elsevier Publishing Company 1, 1-204.

NAmiotKo, T., DAnielopol, D. L., Belmecheri, S., Gross, M. \& VON Grafenstein, U. 2011: On Leptocytheridae ostracods of long-lived Lake Ohrid (Albania/Macedonia). - Joannea Geologie und Paläontologie 11, 151-153.

Nazik, A., Tuerkmen, I., Koc, C., Aksoy, E., Avşar, N. \& YayıK, H. 2008: Fresh and Brackish Water Ostracods of Upper Miocene Deposits, Arguvan/Malatya (Eastern Anatolia). - Turkish Journal of Earth Sciences 17/3, 481-495.

OltEANu, R. 1971: Studiul ostracodelor din depozitete pannonian-superioare (zona E) de la Groşi (Banat). - Dări de seamă ale şedințelor Institutul de Geologie şi Geofizică, 3. Paleontologie, 57, 85-101.

Olteanu, R. 1989: The "Cimpia Moment" (late Miocene, Romania) and the Pannonian-Pontian boundary, defined by ostracods. Journal of Micropalaeontology 8/2,239-247. https://doi.org/10.1144/jm.8.2.239.

Olteanu, R. 2011: Atlas of the Pannonian and Pontian ostracods from the Eastern area of the Pannonian Basin. - Geo-Eco-Marina 17, 135-177. http://doi.org/10.5281/zenodo.56927.

PIPÍK, R. \& HolEC, P. 1998: Panónske lastúrničky (Crustacea, Ostracoda) a stavovce (Chordata, Vertebrata) z hliniska tehelne v Borskom Svätom Jure. - Mineralia Slovaca 30, 185-194.

Pipík, R., Fordinál, K., Slamková, M., Starek, D. \& Chalupová, B. 2004: Annotated checklist of the Pannonian microflora, evertebrate and vertebrate community from Studienka, Vienna Basin. - Scripta Facultatis Scientiarum Naturalium Universitatis Masarykianae Brunensis 31, 47-54.

POKORNÝ, V. 1944: La microstratigraphie du Pannonien entre Hodonín et Mikulčice (Moravie méridionale, Tchecoslovaquie). - Bulletin International, Académie Tchèque des Sciences Prague 23, 1-25.

POKORNÝ, V. 1952: The ostracods of the so-called basal-horizon of the Subglobosa Beds at Hodonín (Pliocene). - Sbornik Ústřední Ústav Geologický, Oddil Paleontologicky 19, 229-396.

Puri, H. S., Bonaduce, G. \& Gervasio, A. M. 1969. Distribution of Ostracoda in the Mediterranean. - In: NeALE, J. W. (ed.): The Taxonomy, Morphology and Ecology of Recent Ostracoda. Oliver \& Boyd, Edinburgh, 356-412.

RAdU, E. \& STOICA, M. 2005: Lower Sarmatian microfauna from the hydrogeological Well FA Hârlău (Iaşi county). - Acta Palaeontologica Romaniae 5, 413-421.

Reuss, E. 1850: Die fossilen Entomostraceen des österreichischen Tertiärbeckens. - Haidinger's Naturwissenschaftlichen Abhandlungen 31, 1-92.

Rosati, M., CAntonati, M., Primicerio, R. \& Rossetti, G. 2014: Biogeography and relevant ecological drivers in spring habitats: A review on ostracods of the Western Palearctic. - International Review of Hydrobiology 99/6, 409-424. https://doi.org/10.1002/iroh.201301726.

Rundić, L. 2006: Late Miocene ostracodes of Serbia: morphologic and palaeoenvironmental considerations. - Geološki anali Balkanskoga poluostrva 67, 89 -100. https://doi.org/10.2298/GABP0667089R.

Rundić, L., GANić, M., KNEŽEvić, S. \& Soliman, A. 2011: Upper Miocene Pannonian sediments from Belgrade (Serbia): new evidence and paleoenvironmental considerations. - Geologica Carpathica 62/3, 267-278. http://doi.org/10.2478/v10096-011-0021-z

SANDBERG, P. 1964: The Ostracod genus Cyprideis in the Americas. Stockholm Contribution of Geology 12, 1-178.

Savatenalinton, S. \& Martens, K. 2009: On a freshwater species of the genus Sanyuania Zhao and Han, 1980 (Crustacea, Ostracoda, Loxoconchidae) from Thailand, with a discussion on morphological evolution of the freshwater Loxoconchidae. - Journal of Natural History 43/5-6, 259-285. https://doi.org/10.1080/00222930802590885.

SCHNEIDER, G. F. 1953: Fauna ostracod iz Miotsenovih otlozeni zapadnoi Chasti Ukrainy. - Geologia Sbornik VNIGRI II (V.), $108-109$.

Schweitzer, P. N. \& LohmanN, G. P. 1990: Life-history and the evolution of ontogeny in the ostracode genus Cyprideis. - Paleobiology $16 / 2,107-125$.

Sebe, K., Csillag, G., Dulai, A., Gasparik, M., Magyar, I., Selmeczi, I., Szabó, M., Sztanó, O. \& Szuromi-Korecz, A. 2015: Neogene stratigraphy in the Mecsek region. - In: BARtha, I. R., Kriván, Á., Magyar, I. \& SEBE, K. (eds): Neogene of the Paratethyan Region. 6thWorkshop on the Neogene of Central and South-Eastern Europe. An RCMNS Interim Colloquium. Programme, Abstracts, Field Trip Guidebook, Hungarian Geological Society, Budapest, 102-124. ISBN 978-963-8221-57-5 
Sebe, K., Kovačić, M., Magyar, I., Krizmanić, K., Špelić, M., Bigunac, D., SÜtő-Szenta, M., Kovács, Á., Szuromi-Korecz, A., Bakrač, K., Hajek-Tadesse, V., Troskot-Čorbić, T. \& Sztanó, O. 2020: Correlation of upper Miocene-Pliocene Lake Pannon deposits across the Drava Basin, Croatia and Hungary. - Geologia Croatica 73/3, 177-195. https://doi.org/10.4154/gc.2020.12

Sebe K., Konrád Gy. \& Sztanó O. 2021: An exceptional surface occurrence: the middle to upper Miocene succession of PécsDanitzpuszta (SW Hungary). - Földtani Közlöny 151/3, 235-252.

Sissingh, W. 1972: Late Cenozoic ostracoda of the South Aegean island arc. - PhD thesis. Utrecht University. 187.

SOKAČ, A. 1962: Pannonische Ostrakodenfauna von Donje Selište südwestlich von Glina. - Geološki Vjesnik 15/2, 391-401.

SOKAČ, A. 1967: Pontska fauna ostrakoda jugo-istoročnog pobočja Zagrebačke gore. - Geološki Vjesnik 20, 63-86.

SOKAČ, A. 1972: Pannonian and Pontian ostracode fauna of Mt. Medvednica. - Palaeontologia Jugoslavica 11, 1-140.

SOKAČ, A. 1990: Pontian ostracod fauna in the Pannonian Basin. In: Stevanović, P. M., Nevesskaja, L. A., Marinescu, F I., SoKaĆ, A. \& JÁmbor, Á. (eds): Chronostratigraphie und Neostratotypen Neogen der Westlichen (Zentrale) Paratethys 8, Pontien, JAZUSANU, Zagreb-Belgrade, 672-721.

Spadi, M., Gliozzi, E., Boomer, I., StoicA, M. \& Athersuch, J. 2019: Taxonomic harmonization of Neogene and Quaternary candonid genera (Crustacea, Ostracoda) of the Paratethys. - Journal of Systematic Palaeontology 17/19, 1-34. https://doi.org/10.1080/ 14772019.2018.1545708.

Stoica, M., LaZăr, I., Krijgsman, W., Vasiliev, I., JiPA, D. \& Floroiu, A. 2013: Paleoenvironmental evolution of the East Carpathian foredeep during the late Miocene - early Pliocene (Dacian Basin; Romania). - Global and Planetary Change 103, $135-148$. https://doi.org/10.1016/j.gloplacha.2012.04.004.

SÜTŐNÉ SZENTAI M. 2012: Szervesvázú mikroplankton zónák a szarmata és a pannóniai emeletek határán Magyarországról. (Organic-walled microplankton zones at the boundary of the Sarmatian and Pannonian stages in Hungary.) - e-Acta Naturalia Pannonica 4, 5-34.

Szabó, M., Kocsis, L., Bosnakoff, M. \& Sebe, K. 2021: A diverse Miocene fish assemblage (Chondrichthyes and Osteichthyes) from the Pécs-Danitzpuszta sand pit (Mecsek Mts., Hungary). - Földtani Közlöny 151/4, 363-410.

SzÉLES M. 1963: Szarmáciai és pannóniai korú kagylósrákfauna a Duna-Tisza közi sekély-és mélyfúrásokból. - Földtani Közlöny 93/1, $108-116$.

SzÉLES M. 1982: A Tengelic-2. sz. fúrás pannóniai Ostracoda faunája. - A Magyar Állami Földtani Intézet Évkönyve 65, $235-289$.

SzUROMI-KoreCZ A. 1991: DK-Dunántúl pannóniai s. 1. Ostracoda fauna vizsgálatának eredményei. - PhD thesis, ELTE Általános és Alkalmazott Földtani Tanszék, Budapest, 245.

SzUROMI-KoreCZ A. 1992: A DK-Dunántúl pannóniai s.l. képződményeinek rétegtani értékelése Ostracoda faunájuk alapján. Öslénytani Viták 38, 5-20.

TER BORGH, M. M. 2013: Connections between sedimentary basins during continental collision - how tectonic, surface and sedimentary processes shaped the Paratethys. - Utrecht Studies in Earth Sciences 45, 203 p.

ter Borgh, M., Vasiliev, I., Stoica, M., Knežević, S., Matenco, L., Krijgsman, W. \& Cloetingh, S. 2013: The isolation of the Pannonian basin (Central Paratethys): New constraints from magnetostratigraphy and biostratigraphy. - Global and Planetary Change 103, 99-118. https://doi.org/10.1016/j.gloplacha.2012.10.001.

Tóтн E. 2009: Ốskörnyezeti változások a Középső-Paratethysben a szarmata folyamán a mikrofauna őslénytani és geokémiai vizsgálata alapján. Changements paléoenvironnementaux dans la Paratéthys Centrale pendant le Sarmatien (miocene moyen): étude paléontologique de microfaunes et analyses géochimiques. - PhD thesis, Eötvös Loránd University, Budapest, 158.

Trelea-Paghida, N., Siminuescu,T. \& Costeschi, G. 1970: Ostracodele miocene din podişul Moldovenesc. - Annals of Alexandru Ioan Cuza University of Iaşi Sec. Zb. 16, 107-120.

TunoĞLu, C. \& ÜNAL, A. 2001: Pannonian-Pontian Ostracoda fauna of Gelibolu Neogene Basin (NW Turkey). - Yerbilimleri 23, $167-187$.

ÜNAL, A. 1996: Gelibolu Yarımadası Neojen İstifinin ostrakod biyostratigrafisi, Yüksek Müh. - Ph.D. thesis, Hacettepe Üniversitesi, Ankara, 160.

VAN HARTEN, D. 1975: Size and environmental salinity in the modern euryhaline ostracod Cyprideis torosa (Jones, 1850), a biometrical study. - Palaeogeography, Palaeoclimatology, Palaeoecology 17/1, 35-48. https://doi.org/10.1016/0031-0182(75)90028-0.

VAN HARTEN, D. 1990: The Neogene evolutionary radiation in Cyprideis Jones (Ostracoda: Cytheracea) in the Mediterranean area and the Paratethys. - Courier Forschungsinstitut Senckenberg 123, 191-198.

VAn HARTEN, D. 2000: Variable noding in Cyprideis torosa (Ostracoda, Crustacea): an overview, experimental results and a model from Catastrophe Theory. - Hydrobiologia 419/1, 131-139. https://doi.org/10.1023/A:1003935419364.

WiTT, W. 2011: Mixed ostracod faunas, co-occurrence of marine Oligocene and non-marine Miocene taxa at Pinarhisar, Thrace, Turkey. - Zitteliana 237-254.

ZALÁNYI, B. 1929: Morpho-systematische Studien über fossile Muschelkrebse. - Geologica Hungarica 5, 1-147.

ZALÁNYI, B. 1944: Magyarországi neogén ostracodák (Tisztabereki neogén ostracoda faunák leírása és rétegtani kiértékelése). Geologica Hungarica 21, 5-144.

ZALÁNYI B. 1959: Tihanyi felsố pannon ostracodák. - A Magyar Állami Földtani Intézet Évkönyve 48, $196-216$.

ZHAI, D., XIAO, J., FAN, J., WEN, R. \& PANG, Q. 2015: Differential transport and preservation of the instars of Limnocythere inopinata (Crustacea, Ostracoda) in three large brackish lakes in northern China. - Hydrobiologia 747/1, 1-18. https://doi.org/10.1007/s 10750014-2118-8.

ZoRN, I. 2010: Ostracodal type specimens stored in the paleontological collection of the Geological Survey of Austria. - Jahrbuch der Geologischen Bundesanstalt 150, 263-299.

Manuscript recieved: 12/02/2021 


\section{Plate I - I. tábla}

The depicted specimens are adult individuals. $\mathrm{LV}=$ left valve, $\mathrm{RV}=$ right valve $/ \mathrm{Az}$ ábrákon felnött egyedek szerepelnek oldalnézetben. $L V=b a l$ teknö, $R V=$ jobb teknö 1 - Amnicythere parallela (MÉHEs 1908), RV in lateral view, scale: $200 \mu \mathrm{m}, \mathrm{D} 29$

2 - Cyprideis pannonica (MÉHes 1908), RV in lateral view, scale: $500 \mu \mathrm{m}, \mathrm{D} 8$

3 - Cyprideis ex gr. heterostigma PoKORNÝ 1952, RV in lateral view, scale: $500 \mu \mathrm{m}, \mathrm{D} 219$

4 - Hemicytheria tenustriata (MéHEs 1908), LV in lateral view, juvenile specimen, scale: $200 \mu$ m, D15.

5 - Hemicytheria tenustriata (MéHEs 1908), RV in lateral view, scale: $200 \mu \mathrm{m}, \mathrm{D} 12$

6- Hemicytheria lorenthey (MéHes 1908), RV in lateral view, scale: 500 m, D29

7 - Hemicytheria hungarica (MéHes 1908), LV in lateral view, scale: $200 \mu \mathrm{m}, \mathrm{D} 15$

8 - Hemicytheria hungarica (MÉHEs 1908), RV in lateral view, scale: $250 \mu \mathrm{m}, \mathrm{D} 7$

9 - Loxocorniculina hodonica PoKORNÝ 1952, RV in lateral view, scale: $250 \mu \mathrm{m}, \mathrm{D} 15$

10 - Candona (Candona) aff. postsarmatica Krstić 1972, LV in lateral view, scale: $500 \mu \mathrm{m}$, D8

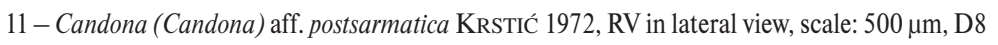

12 - Candona (Propontoniella) macra KRSTIĆ 1972, RV in lateral view, scale: 250 um, D4

13 - Candona (Propontoniella) candeo KRSTIĆ 1972, RV in lateral view, scale: $200 \mu$ m, D213

14 - Candona (Reticulocandona) reticulata (MéHes 1908), LV in lateral view, scale: 500 m, D216

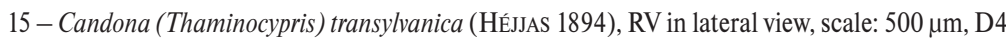

16 - Candona (Thaminocypris) transylvanica (HÉJJAS 1894), LV in lateral view, scale: $500 \mu \mathrm{m}$, D7

17 - Candona (Sinegubiella) rakosiensis (MéHEs 1907), LV in lateral view, scale: $200 \mu \mathrm{m}$, D213

18 - Candona (Thyphlocypris) cf. fossulata POKORNÝ 1952, RV in lateral view, scale: $250 \mu \mathrm{m}$, D14 

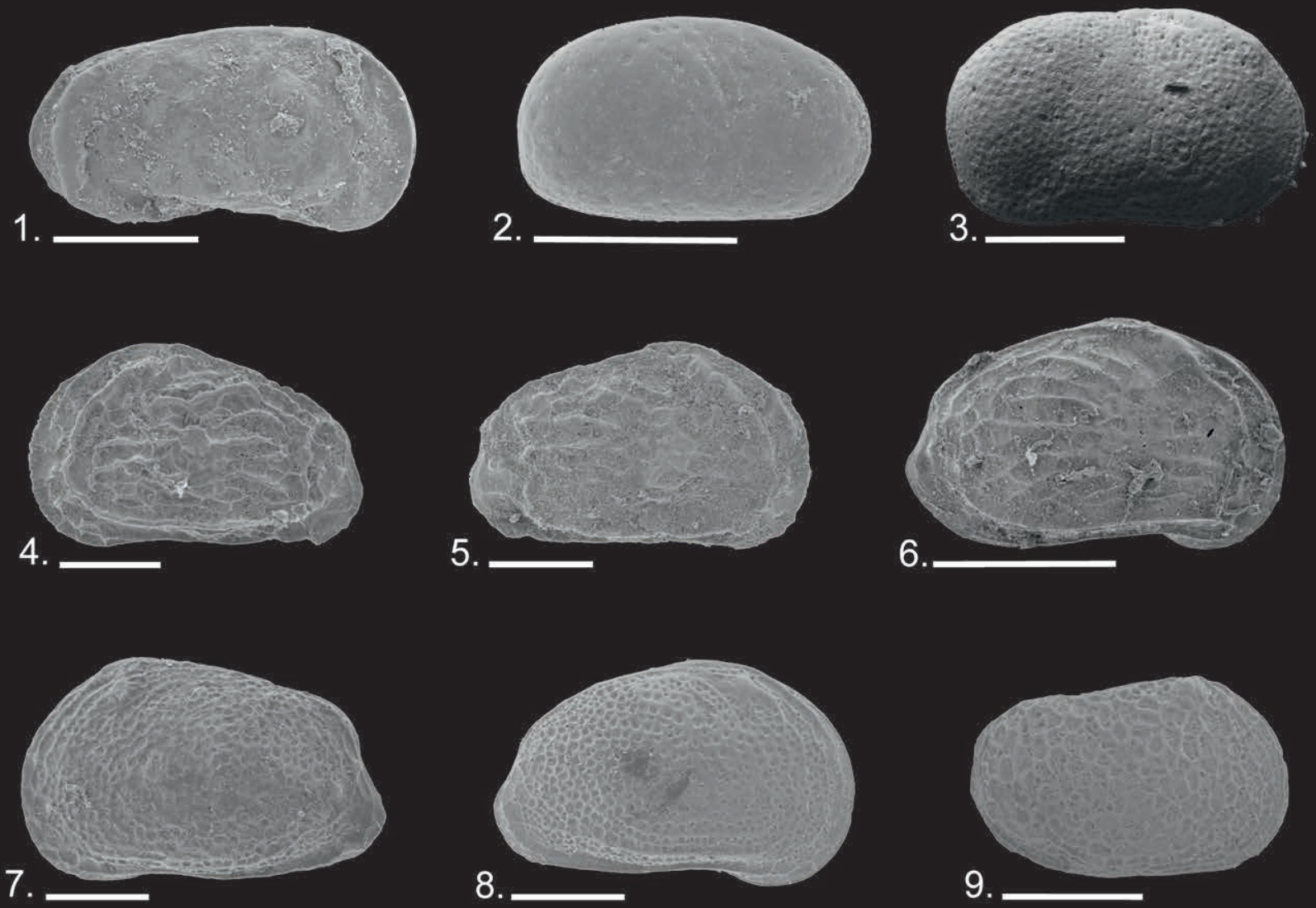

10.
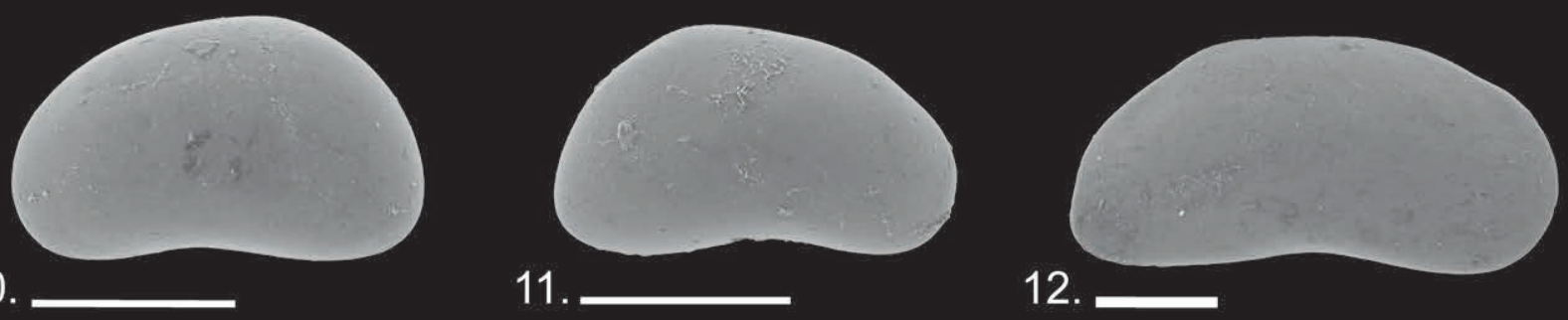

13

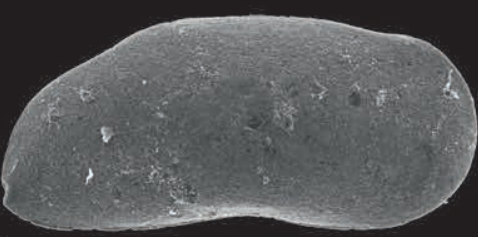

3.

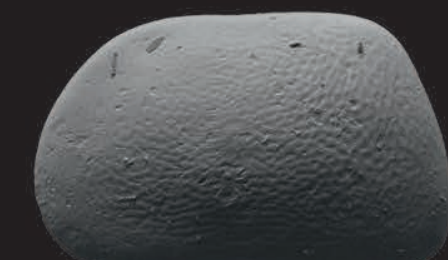

14.

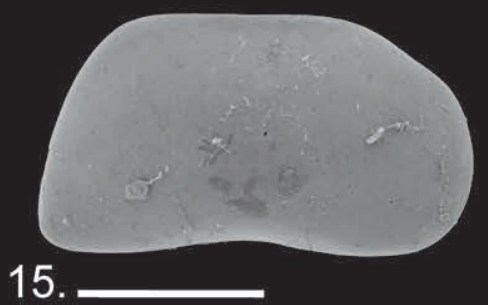

16.
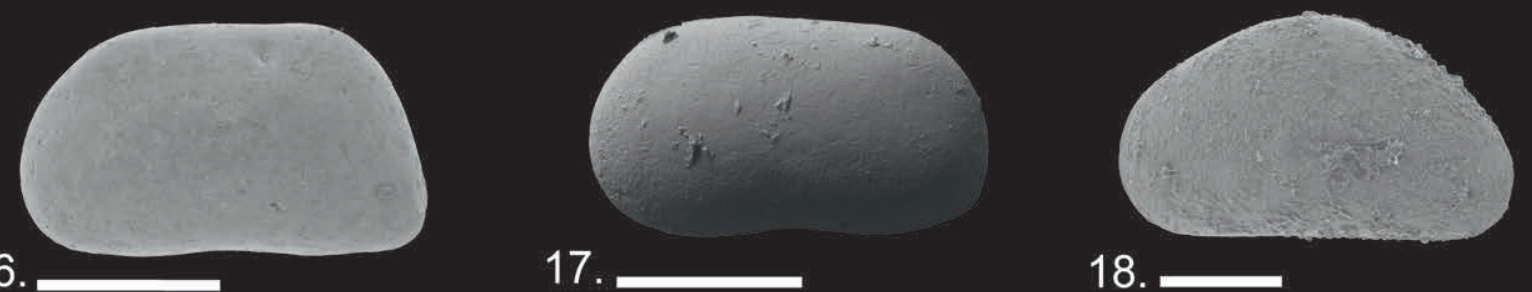


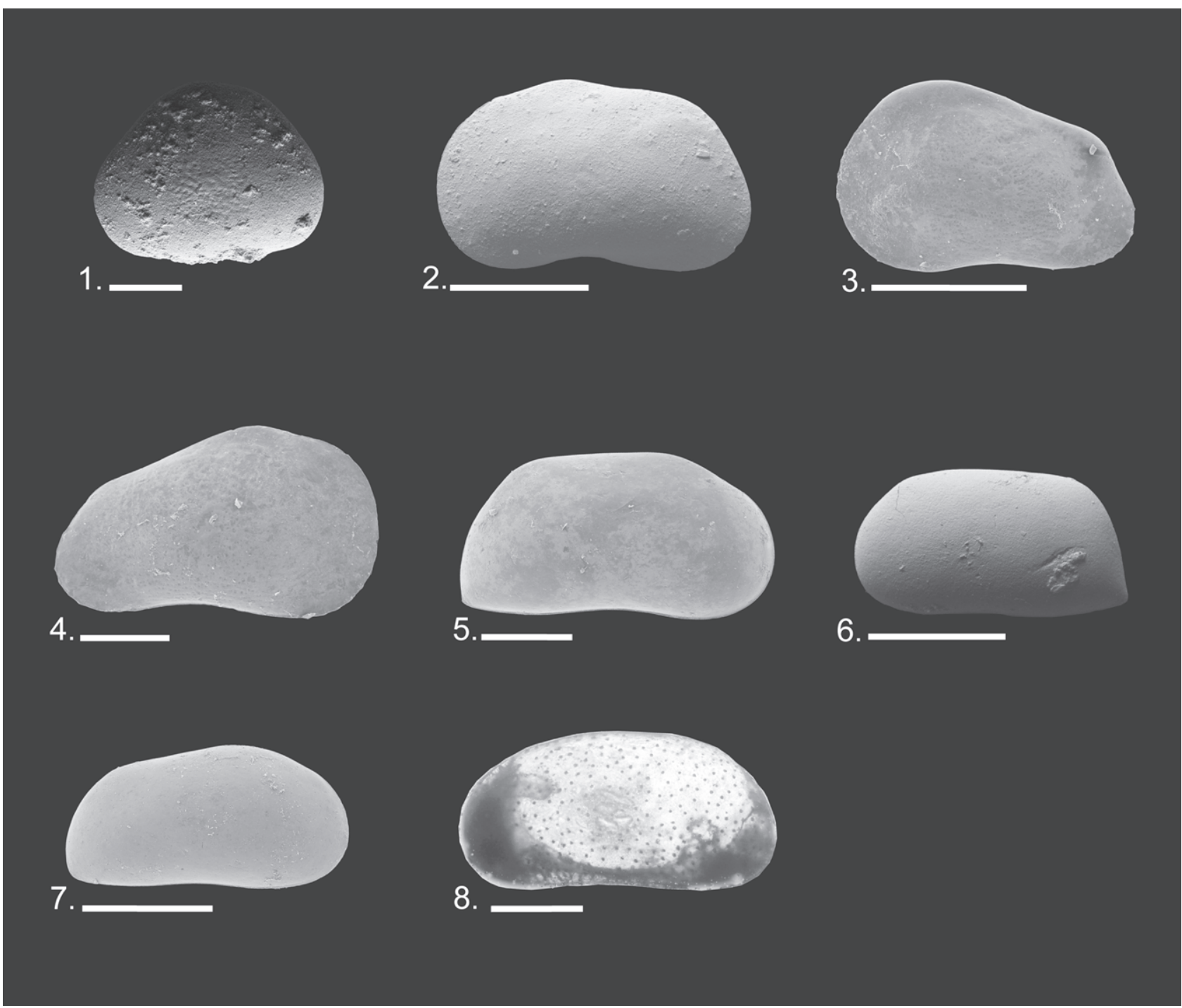

Plate II - II. tábla

Where not indicated otherwise, the depicted specimens are adult individuals. $\mathrm{LV}=$ left valve, $\mathrm{RV}=$ right valve $/$ A 3, 4, 6. ábrán juvenilis, a többin felnött egyedek szerepelnek oldalnézetben. $L V=$ bal teknö, $R V=$ jobb teknö

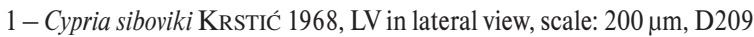

2 - Herpetocyprella auriculata (Reuss 1850), LV in lateral view, scale: $500 \mu \mathrm{m}, \mathrm{D} 200$

3 - Herpetocyprella hieroglyphica (MéHEs 1907), juvenile LV in lateral view, scale: $500 \mu \mathrm{m}, \mathrm{D} 9$

4 - Herpetocyprella hieroglyphica (MéHEs 1907), juvenile RV in lateral view, scale: $250 \mu \mathrm{m}$, D9

5-Amplocypris abscissa (Reuss 1850), RV in lateral view, scale: $500 \mu \mathrm{m}, \mathrm{D} 213$

6 - Amplocypris major KRSTIĆ 1973, juvenile LV in lateral view, scale: $250 \mu$ m, D213

7 -Amplocypris firmus KRsTIĆ 1973, RV in lateral view, scale: $500 \mu \mathrm{m}, \mathrm{D} 4$

8 -Amplocypris recta (Reuss 1850), LV in lateral view, scale: $500 \mu \mathrm{m}, \mathrm{D} 15$ 


\section{Appendix}

\section{Systematic Palaeontology}

Here we follow the classification of HoRNE et al. (2002) and HARTMANN \& PURI (1974). The lists of synonyms and the Stratigraphic range and geographic distribution sections contain items which were published with proper illustrations of specimens. The Pécs-Danitzpuszta specimens are deposited in the Department of Palaeontology, Eötvös Loránd University, Budapest. Abbreviations: L: length, H: height.

Phylum Arthropoda SiEBOLD \& STANNIUS 1845

Subphylum Crustacea PENNANT 1777

Class Ostracoda LATREILLE 1802

Order Podocopida MÜLLER 1894

Suborder Cytherocopina BAIRD, 1850

Superfamily Cytheroidea BAIRD, 1850

Family Leptocytheridae HANAI 1957

Genus Amnicythere Devoto 1965

\section{Amnicythere parallela (MÉHES, 1908)}

\section{Plate I, fig. 1}

1908 Krithe parallela n. sp. - MÉHES, pp. 550-551, pl. 10, figs 1-3. 1960 Leptocythere parallela (MÉHES) - KRSTIĆ, p. 279, pl. 1, figs

19-20; pl. 2, figs 22-33; pl. 3, figs 16-17; pl. 4, figs 6, 7, 10-16. 1972 Leptocythere parallela (MÉHES) - SoKAČ, p. 66, pl. 30, figs 4, 7-10.

1973a Leptocythere (Amnicythere) parallela (MÉHES) - KRSTIĆ, pp. 57-58, figs 4-11; pl. 5, figs 1-3; pl. 6, fig. 5 .

1973a Leptocythere (Amnicythere) aff. parallela (MÉHES) KRSTIĆ, pp. 58-59, figs 12-16; pl. 1, fig. 6.

1980 Leptocythere parallela (MÉHES) - IONESI \& CHINTAUAN, pl. 1, fig. 3.

1982 Leptocythere parallela (MÉHES) - SZÉLES, p. 252, fig.12.

1985 Leptocythere (Amnicythere) aff. parallela (MÉHES) - KRSTIĆ, pl. 11, fig. 4.

1986 Leptocythere parallela (MÉHES) - IONESI \& CHINTAUAN, pl. 1, fig. 8 .

Material: Danitzpuszta trench (4 valves)

Dimensions: $\mathrm{L}=485.930-583.422 \mu \mathrm{m}, \mathrm{H}=242.577-$ $288.425 \mu \mathrm{m}, \mathrm{L} / \mathrm{H}=2.003-2,23 \mu \mathrm{m}$

Stratigraphic range and geographic distribution: lower Sarmatian (Volhynian) and Maeotian of the Euxinian Basin and lower Pannonian of the Pannonian Basin: Sarmatian (upper Volhynian) of Southern Dobrogea (IONESI \& Chintauan 1986); Maeotian of Moldova (IONESI \& Chintauan, 1980); Pannonian of the Vienna Basin in the Czech Republic and Mt. Medvednica in Croatia (SOKAČ
1972), Sopron (Darufalva) (MéHES 1908) and Tengelic (SzÉles 1982) in Hungary, Prnjavor in Bosnia (KRSTić 1985), and Malo Bučje, Velika Moštanica, Sibovik-5, Vrčin in Serbia (KRSTIĆ 1960, 1973a).

Family Cytherideidae SARS 1925

Subfamily Cytherideinae SARS 1925

Genus Cyprideis JoNes 1857

\section{Cyprideis pannonica (MÉHES, 1908)}

Plate I, fig. 2

1908 Cytheridea pannonica n. sp. - MÉHES, pp. 553-555, pl. 11, figs 6-14.

1929 Cytheridea pannonica MÉHES - ZALÁNYI, p. 73, textfig 351: 10, 361: 6 .

1944 Cytheridea pannonica MÉHES - ZALÁNYI, p. 90, p. 172.

1944 Cyprideis pannonica (MÉHES) - POKORNÝ, pp. 292-293, pl. 1 , figs $3-4$.

1960 Cyprideis pannonica (MéHES) - Kollmann, p. 163, pl. 13, figs $1-4$.

1959 Cyprideis pannonica (MÉHES) - ZALÁNYI, p. 213.

1963 Cyprideis pannonica (MÉHES) - SzÉLES, pl. 6, figs 1-2.

1966 Cyprideis pannonica (MÉHes) - HANGANU, pl. 40. fig. 2.

1968a. Cyprideis (Cyprideis) cf. pannonica (MÉHES) - KRSTIĆ, p.

111, pl. 1, figs 2-3.

1970 Cyprideis pannonica (MÉHES) - TRELEA et al. pp. 111-112, pl. 3 , figs $10 \mathrm{a}-\mathrm{c}$.

1973 Cyprideis pannonica (MÉHES) - BENSON, text-fig. 2, E-F.

1974 Cyprideis pannonica (MÉHES) - CERNAJSEK, pp. 473-474, pl.

2, fig. 5.

1975 Cyprideis pannonica (MÉHES) - IONESI \& CHINTAUAN, pl. 1, fig. 3.

1976 Cyprideis pannonica (MéHES) - CHINTAUAN \& NiCORICI, p.

12, pl. 1, figs 5-7.

1978 Cyprideis pannonica (MéHES) - CARBONNEL, pl. 1, figs 11-13. 1978 Cyprideis pannonica (MéHEs) - BENSON, pl. 2, figs 4-8.

1979 Cyprideis (Cyprideis) pannonica (MÉHES) - BASSIOUNI, pp. 84-85, pl. 1, figs $1-6$.

1980 Cyprideis pannonica (MÉHES) - IONESI \& CHINTAUAN, pl. 1, fig. 2.

1983 Cyprideis pannonica (MÉHES) - JIŘIČEK, pl. 6, fig. 32.

1985 Cyprideis pannonica (MÉHES) - IONESI \& CHINTAUAN, pl. 1, fig. 2.

1985 Cyprideis pannonica (MÉHES) - JIŘIČEK, p. 396, pl. 53, figs $1-4$.

1990 Cyprideis (Cyprideis) ex. gr. pannonica - KRSTIĆ \& STANCHEVA, pl. 9, fig. 10. 
1996 Cyprideis pannonica (MÉHES) - ÜNAL, p. 92, pl. 1, fig. 9-11. 1998 Cyprideis pannonica (MÉHES) - KovÁč et al., pl. 4, figs 5-6. 2000 Cyprideis pannonica (MÉHes) - CHINTAUAN, pl. 1, fig. 7.

2001 Cyprideis pannonica (MÉHES) - TUNOĞLU \& ÜNAL, p. 171, pl. 1, fig. 8.

2005 Cyprideis pannonica (MÉHES) - RADU \& STOICA, pl. 2, figs 9-11. 2008 Cyprideis pannonica (MÉHES) - NAZIK et al., pl. 1, figs 8-9.

2008 Cyprideis pannonica (MÉHES) - BEKER et al., p. 9, pl. 1, figs $1-3$.

2011 Cyprideis pannonica (MÉHES, 1908) - WitT, pl. 1, fig. 1.

2011 Cyprideis pannonica (MÉHES) - FILIPESCU et al., text-fig. 5, fig. 15.

2013 Cyprideis pannonica (MÉHES) - StolCA et al., pl. 2, fig. 1.

Material: Danitzpuszta trench (4 valves)

Dimensions: $\mathrm{L}=851.243-875 \mu \mathrm{m} \mathrm{H}=475.02-501.493$ $\mu \mathrm{m}, \mathrm{L} / \mathrm{H}=1.745-1.792$

Stratigraphic range and geographic distribution: Sarmatian to Pannonian of the Pannonian Basin system, Sarmatian to Meotian of the Dacian Basin, Sarmatian of the Euxinian Basin, upper Miocene of the Aegean Basin, Messinian of the Eastern Mediterranean Basin, upper Miocene to PlioPleistocene of continental Turkey: Sarmatian in Nexing in Austria (Cernajsek 1974); Tusa (Chintauan \& Nicorici 1976), Livezile (Chintauan 2000), and Oarba de Mureş (FILIPESCu et al. 2011) in Transylvania, Romania; Pannonian in Malacky M-16 borehole in Slovakia (KovéČ et al. 1998); Hodonín (POKORNÝ 1944; JiŘIČEK 1983, 1985) and Svatobořice-Mistřín (CARBOnNel 1978) in the Czech Republic; Drassburg in Austria (Kollmann 1960); Sopron, Peremarton, Budapest-Kőbánya, Tisztaberek, Duna-Tisza Interfluve (MÉHES, 1908, ZALÁNYI 1944, SZÉLES 1963) and Tihany (ZALÁNYI 1959) in Hungary; Badnjevac, Varovnica in Serbia (ZALÁNYI 1929, KRSTIĆ 1968a); Krško in Slovenia (Krstić \& Stancheva 1990); Szócsán/Soceni in Transylvania, Romania (MéHES 1908); Sarmatian in Hârlău (Trelea et al. 1970, Radu \& Stoica 2005), Siret and Moldova valleys (IONESI \& ChintAUAN 1975, 1980) in Romania; Meotian at Teleajen river, Prahova, Brătești (HANGanu 1966, IONESI \& Chintauan, 1980) and Rămnicu Sărat (STOICA et al. 2013) in Romania; Sarmatian in Pinarhisar in Turkey (WITT 2011) and Văleni (Dobrogea) in Romania (IONESI \& Chintauan 1985); ?upper Miocene („Pannonian and Pontian") in Gelibolu BE-18 in Turkey (ÜNAL 1996; TUNOĞLU \& ÜNAL 2001); Messinian in DSDP Leg 42A, Site 376, Florence Rise, W of Cyprus (BENson 1978) and DSDP Leg 13, Site 129, Hole 129A, Levantine Basin (Benson 1973); upper Miocene in Arguvan, Malatya in Turkey (BASSIOUNI 1979; NAZIK et al. 2008); Plio-Pleistocene in Karapınar-Konya in Turkey (BEKER et al. 2008).

Cyprideis ex gr. heterostigma POKORNÝ, 1952 Plate I, fig. 3

Material: Danitzpuszta pit (256 valves, 1 carapace)

Dimensions: $\mathrm{L}=570.382-1130 \mu \mathrm{m}, \mathrm{H}=309.585-663$ $\mu \mathrm{m}, \mathrm{L} / \mathrm{H}=1.704-1.842$

Remarks: The anterodorsal outline shows a variability in convexity, maybe due to sexual dimorphism. There is significant variability in the convexity of the valves as well; it is difficult to decide whether it reflects intraspecific variation or higher convexity is a diagnostic morphological character of another species. There are more adults than juveniles.

Family Hemicytheridae PURI 1953

Subfamily Hemicytherinae PURI 1953

Genus Hemicytheria POKORNÝ 1952

Hemicytheria tenuistriata (MÉHES, 1908)

Plate I, figs 4-5

1908 Cythereis tenuistriata n. sp. - MÉHES, pp. 559-561, text-figs 5-10.

1985 Graptocythere (Hemicytheria) tenuistriata (MÉHES) KRSTí́, pl. 13, fig. 5.

2011 Hemicytheria tenuistriata (MÉHes) - OlteAnu, pl. 26, fig. 8.

2013 Hemicytheria tenuistriata (MÉHEs) - TER BORGH et al., pl. 8, fig. 5 .

Material: Danitzpuszta pit (13 valves); Danitzpuszta trench (19 valves)

Dimensions: $\mathrm{L}=399-802.624 \mu \mathrm{m} \mathrm{H}=247-476.447 \mu \mathrm{m}$, $\mathrm{L} / \mathrm{H}=1.615-1.685$

Stratigraphic range and geographic distribution: lower Pannonian in the Pannonian Basin: Sopron in Hungary (MÉHes 1908); Velika Moštanica (Krstić 1985) and Beočin (TER BORGH et al. 2013) in Serbia.

\section{Hemicytheria lorentheyi (MÉHES, 1908) Plate I, fig. 6}

1908 Cythereis Lörentheyi n. sp. - MÉHES, pp. 561-562, pl. 8, figs $1-6$.

1960 Hemicytheria lörentheyi (MÉHES) - KRSTIĆ, p.280, pl. 1, fig. 23; pl. 3, fig. 20; pl. 4, fig. 5 .

1969 Hemicytheria cf. loerenthei (MÉHES) - GRAMANN, pp. 501, pl. 35 , fig. 4.

1972 Hemicytheria lôrentheyi (MéHES) - IONESI \& CHINTAUAN, pp. 101-102, pl. 5, fig. 4.

1983 Hemicytheria lorentheyi (MÉHES) - JIŘIČEK, pl. 6, fig. 31.

1985 Hemicytheria lorentheyi (MÉHES) - JIŘıČEK, p. 405, pl. 56, figs 4-6.

2004 Hemicytheria lorentheyi (MÉHES) - GROss, p. 86, pl. 13, figs 5-6; pl. 14 fig. 9.

Material: Danitzpuszta trench (1 valve)

Dimensions: $\mathrm{L}=1003.76 \mu \mathrm{m} \mathrm{H}=591.47 \mu \mathrm{m}, \mathrm{L} / \mathrm{H}=$ 1.697

Stratigraphic range and geographic distribution: Sarmatian of the Euxinian Basin, lower Pannonian of the Pannonian Basin, and Messinian (Meotian-Pontian) of the Aegean (Strymon) Basin: Sarmatian of Moldova (IONESI \& Chintauan, 1972); lower Pannonian of Sopron, BudapestKőbánya, Peremarton, Hungary (MÉHes 1908); Belgrade, Serbia (KRSTIĆ 1960); Mataschen, Austria (GROSS 2004); Bučany-48, Slovakia (JIŘIČEK 1983); Mutěnice, Czech Republic (JIŘIČEK, 1985); Messinian (Meotian-Pontian) of Strymon Basin (GRAMANN 1969). 
Hemicytheria hungarica (MÉHES, 1908)

Plate I. figs 7-8

1908 Cythereis hungarica n. sp. - MÉHES, pp. 562-563, pl. 8, figs 7-9.

2009 Hemicytheria hungarica (MÉHES) - TóTH, p. 89, pl. 5, figs 45 cum. syn.

2010 Hemicytheria hungarica (MÉHES) - ZoRN, p. 266, pl. 1, fig. 13.

Material: Danitzpuszta pit (6 valves); Danitzpuszta trench (27 valves)

Dimensions: $\mathrm{L}=531.444-823.895 \mu \mathrm{m} \mathrm{H}=301.321-$ $483.859 \mu \mathrm{m}, \mathrm{L} / \mathrm{H}=1.703-1.763$

Stratigraphic range and geographic distribution: Sarmatian of the Euxinian Basin, Sarmatian and lower Pannonian of the Pannonian Basin system: Sarmatian of the Caucasus region (SCHNEIDER, 1953); Sarmatian of the Danube Basin, Slovakia (DoRNIČ \& KHEIL 1963) and Csákvár, Hungary (TóTH 2009); lower Pannonian of Sopron (Darufalva) and Budapest-Kőbánya in Hungary (MÉHES 1908); Prnjavor in Bosnia (KRSTić 1985); Drassburg in Austria (ZORN 2010).

Family Loxoconchidae SARS 1925

Genus Loxocorniculina KRSTIĆ 1972

\section{Loxocorniculina hodonica POKORNÝ, 1952} Plate I, fig. 9

1952 Loxoconcha hodonica n. sp. - POKORNÝ, pp. 308-309, pl. 5, figs 1, 2, 9, figs 36-37.

1960 Loxoconcha hodonica POKORNÝ - KRSTIĆ, p. 281, pl. 2, fig. 28. 1963 Loxoconcha hodonica POKORNÝ - GREKOFF \& MOLINARI, p. 5 , pl.2, figs 5-6.

1966 Loxoconcha hodonica POKORNÝ - HANGANU, pl. 43, fig. 3.

1969 Loxoconcha cf. hodonica POKORNÝ - GRAMAnN, pp. 509510, pl. 34, figs 1-2.

1972 Loxoconcha hodonica POKORNÝ - SOKAČ, pp. 84-85, pl. 44, figs 6-7.

1972a. Loxoconcha (Loxocorniculina) hodonica POKORNÝ KRSTić, p. 253, pl. 4, fig. 7; pl. 6, figs 4-6.

1972 Loxoconcha hodonica POKORNÝ - SISSINGH, p. 133, pl. 10, figs $15-16$.

1985 Loxoconcha (Loxocorniculina) hodonica POKORNÝ - KRSTIĆ, pl. 12, fig. 10.

2013 Loxocorniculina hodonica (POKORNÝ) - TER BORGH et al., text-fig. 8, 30 .

2016 Loxocorniculina hodonica POKORNÝ - KovÁCs et al., pl. 3, figs $2-3$.

Material: Danitzpuszta trench (4 valves)

Dimensions: $\mathrm{L}=475-535.852 \mu \mathrm{m} \mathrm{H}=322.242-325 \mu \mathrm{m}$, $\mathrm{L} / \mathrm{H}=1.474-1.648$

Stratigraphic range and geographic distribution: lower Pannonian of the Pannonian Basin system, Meotian of the Dacian Basin, Messinian of the Mediterranean Basin: lower Pannonian of Hodonín in the Czech Republic (POKORNÝ 1952); Mt. Medvednica in Croatia (SoKAČ 1972); Velika Moštanica, Sibovik-2a, Velika Plana, Vrčin, Belgrade, Makiš, and Beočin in Serbia (KRSTić 1960, 1972a, 1985;
TER Borgh et al. 2013); Lopadea Veche and Gârbovița in Transylvania, Romania (Kovícs et al. 2016); Maeotian of Teleajen River valley, Prahova in Romania (Hanganu 1966); Messinian (Meotian-Pontian) of the Strymon Basin (Gramann 1969); Messinian (?) of Crete (Sissingh 1972); Messinian of Reggio Emilia in Italy (GREKOFF \& MoLINARI 1963).

Superfamily Cypridoidea BAIRD 1845

Family Candonidae KaUfMAnN 1900

Subfamily Candoninae KAUFMANN 1900

Genus Candona BAIRD 1845

Candona (Candona) aff. postsarmatica KRSTIĆ, 1972 Plate I, figs 10-11

1972b. Candona (Candona) postsarmatica n. sp. - KRSTIĆ, pp. 911, pl. 2, figs 4-6; p. 113.

1972b. Candona aff. postsarmatica n. sp. - KRSTIĆ, pl. 4, fig. 2.

1980a. Candona (Candona) aff. postsarmatica KRSTIĆ - KRSTIĆ, fig. 10.

1985 Candona (Candona) postsarmatica KRSTIĆ - KRSTIĆ, pl. 3, fig. 2 .

2011 Candona (Caspiocypris) postsarmatica-OLTEANU, pl. 2, fig. 1.

2013 Candona (Caspiocypris) postsarmatica - MAZZINI et al., pl. 2 , fig. e.

Material: Danitzpuszta trench (10 valves)

Dimensions: L = 971.880-1000.739 $\mu \mathrm{m} \mathrm{H}=511.266-$ $554.633 \mu \mathrm{m}, \mathrm{L} / \mathrm{H}=1.804-1.9$

Remark: In her original publication KRSTIĆ depicted only females, without giving their size. Our specimens have more rounded outline, but it is difficult to decide if this difference is due to sexual dimorphism, ontogenetic state, or our material represents a different species.

Stratigraphic range and geographic distribution of $C$. postsarmatica: lower Pannonian of the Pannonian Basin system, Tortonian of Turkey: lower Pannonian of Belgrade and Aleksinac in Serbia (KRSTIĆ 1972b, 1980a, 1985); Carand in Transylvania, Romania (OlteAnu 2011); Tortonian of Çankiri Basin, Tuğlu, in Turkey (MAZZINI et al. 2013).

\section{Candona (Propontoniella) macra KRSTIĆ, 1972} Plate I, fig. 12

1972b. Candona (Propontoniella) macra - KRSTÍ́, pp. 35-36, pl. 11, figs 15-18, p. 123.

1985 Candona (Propontoniella) macra - KRSTIĆ, pl. 1, fig. 9.

2016 Candona (Propontoniella) macra KRSTIĆ - KovÁcs et al., pl. 2, figs 9-12.

2019 Propontoniella macra - SPADI et al., text-fig 3, I; text-fig 16, F-I.

Material: Danitzpuszta pit (2 valves); Danitzpuszta trench (15 valves)

Dimensions: $\mathrm{L}=725-984.157 \mu \mathrm{m} \mathrm{H}=350-442.223 \mu \mathrm{m}$, $\mathrm{L} / \mathrm{H}=2.071-2.225$

Stratigraphic range and geographic distribution: lower Pannonian of the Pannonian Basin system: Vranović-1, Mt. 
Krndija, Croatia (SPADI et al. 2019); Velika Moštanica, Sibovik (Belgrade) in Serbia (KRSTIĆ 1972b, 1985); Cunța in Transylvania, Romania (KovÁcs et al. 2016).

\section{Candona (Propontoniella) candeo Krstić, 1972} Plate I, fig. 13

1972b. Candona (Propontoniella) candeo - KRstić, pp. 36-37, pl. 4, fig. 10; pl. 11, figs 1-4, figs 29-32; p. 124.

1985 Candona (Propontoniella) candeo - Krstí́, pl. 2, fig. 3-6.

Material: Danitzpuszta pit (29 valves)

Dimensions: $\mathrm{L}=736.87-827.2 \mu \mathrm{m} \mathrm{H}=339.65-359.49$ $\mu \mathrm{m} \mathrm{L} / \mathrm{H}=2.3-2.44$

Stratigraphic range and geographic distribution: lower Pannonian of the Pannonian Basin: Velika Moštanica, Sibovik creek in Serbia (KRSTIĆ 1972b, 1985).

\section{Candona (Reticulocandona) reticulata (MÉHES, 1907) Plate I, fig. 14}

1907 Aglaia reticulata n. sp. - MÉHES, pp. 442-443, pl. 3, figs 10-14. 1962 Candona (Lineocypris) reticulata (MéHES) -SOKAČ, pl. 1, fig. 6. 1963 Candona (Lineocypris) reticulata MÉHES - SzÉLES, pl. 5, fig. 5. 1971 Candona (Lineocypris) reticulata (MéHes) - Olteanu, p. 91, pl. 3, fig. 3 .

1972b. Candona (Reticulocandona) reticulata (MÉHES) - KRSTIĆ, pp. 59-60, pl. 17, figs 1-2, 6-7; pl. 24, fig. 7; figs 48-49.

1972 Candona (Lineocypris) reticulata (MÉHES) - SOKAČ, pp. 53 54, pl. 23, figs 12-16.

1980b. Candona (Reticulocandona) reticulata (MÉHES) - KRSTIĆ, pl. 2, figs 4-6.

1982 Candona (Lineocypris) reticulata MÉHes - SzÉLES, p. 241, pl. 4, figs 2, 4-5.

2011 Candona (Reticulocandona) reticulata (MÉHES) - OLtEANU, pl. 9 , fig. 4.

2011 Reticulocandona reticulata (MÉHES) - RuNDIĆ et al., pl. 9, figs $9-10$.

Material: Danitzpuszta pit (10 valves)

Dimensions: $\mathrm{L}=476.585-530.056 \mu \mathrm{m}, \mathrm{H}=276.246-$ $333.957 \mu \mathrm{m}, \mathrm{L} / \mathrm{H}=1.587-1.725$

Remark: Although the the posterodorsal rim is variable, each individual has a diagnostic fine reticulation on the valve surface.

Stratigraphic range and geographic distribution: Pannonian of the Pannonian Basin: Szócsán/Soceni in Transylvania, Romania (MéHES 1907); Budapest-Kőbánya, Danube-Tisza Interfluve, Tengelic in Hungary (MÉHES 1907; SzÉles 1963, 1982); Mt. Medvednica in Croatia (SoKAČ 1962, 1972); Beočin, Belgrade (ZV-3) in Serbia (KRSTIĆ 1972b, 1980b; RundiĆ et al. 2011); Groşi, Rieni in Transylvania, Romania (OlteAnU 1971, 2011).

Candona (Thaminocypris) transylvanica (HÉJJAS, 1894) Plate I, figs 15-16

1894 Candona reticulata n. sp. - HÉJJAs, p. 63, pl. 4, figs 14 a, b, c. 1972b. Candona (Thaminocypris) cf. transylvanica (HÉJJAS) KRSTIĆ, pp. 63-64, pl. 18, fig. 8.

2016 Candona (Caspiocypris) transilvanica (HÉJJAS) - KovÁCs et al., pl. 2, figs 5-8, 13-15.
Material: Danitzpuszta pit (18 valves); Danitzpuszta trench (40 valves)

Dimensions: $\mathrm{L}=1035.667-1128.067 \mu \mathrm{m} \mathrm{H}=558.371-$ $669.064 \mu \mathrm{m}, \mathrm{L} / \mathrm{H}=1.686-1.854$

Stratigraphic range and geographic distribution: lower Pannonian of the Pannonian Basin: Belgrade ("London" C2) in Serbia (KRSTIĆ 1972b); Târgu Mureş, Băgău, Miercurea Nirajului, Lopadea Veche, Gârbovița, Cunța in Transylvania, Romania (HÉJJAS 1894, KovÁcs et al. 2016).

Candona (Sinegubiella) rakosiensis (MÉHES, 1907) Plate I, fig. 17

1907 Aglaia rákosiensis n. sp. - MÉHES, pp. 513-514, pl. 6, figs 813.

1972b. Candona (Sinegubiella) rakosiensis (MÉHES) - KRSTIĆ, p. 80, pl. 25, figs 8-11, pl. 30, fig. 1 .

1972 Candona (Caspiocypris) rakosiensis (MÉHES) - SOKAČ, p. 39 , pl. 15, figs $1-3$.

Material: Danitzpuszta pit (4 valves)

Dimensions: $\mathrm{L}=440-549.131 \mu \mathrm{m} \mathrm{H}=230-289.469 \mu \mathrm{m}$, $\mathrm{L} / \mathrm{H}=1.897-1.913$

Stratigraphic range and geographic distribution: lower Pannonian of the Pannonian Basin: Sopron, BudapestKőbánya in Hungary (MéHes 1907); Mt. Medvednica in Croatia (SOKAČ 1972); Đurinci in Serbia (KRSTIĆ 1972b).

Candona (Typhlocypris) cf. fossulata POKORNÝ, 1952 Plate I, fig. 18

1952 Candona fossulata n. sp. - POKORNÝ, pp. 264-266, text-fig. 11, $12 ;$ pl. 2 fig. 1.

1972 Candona (Typhlocypris) fossulata POKORNÝ - SOKAČ, pp. 59-60, pl. 28, fig. 1.

1972b. Candona (Typhlocypris) aff. fossulata POKORNÝ - KRSTIĆ, p. 84 , pl. 24, fig. 12 ; pl. 27, figs 4-7.

1980 Candona (Typhlocypris) ex. gr. fossulata POKORNÝ - FreEls, pp. 63-64, pl. 9, figs 21-26.

Material: Danitzpuszta trench (10 valves)

Dimensions: $\mathrm{L}=828.630-1025 \mu \mathrm{m} \mathrm{H}=460.177-550$ $\mu \mathrm{m}, \mathrm{L} / \mathrm{H}=1.801-1.863$

Remark: The postero-dorsal and the ventral margin is more rounded than in the holotype.

Stratigraphic range and geographic distribution of $C$. fossulata: lower Pannonian of the Pannonian Basin, upper Miocene of Turkey: lower Pannonian in Hodonín in Czech Republic (POKORNÝ 1952); Mt. Medvednica in Croatia (SOKAČ 1972); Karagača creek in Serbia (KRSTIĆ 1972b); upper Miocene of Denizli basin in Turkey (FrEELs 1980).

Subfamily Cyclocypridinae KAUFMANN 1900 Genus Cypria FISCHER 1855

\section{Cypria siboviki KRSTIĆ, 1968 Plate II, fig 1}

1968b. Cypria siboviki n. sp. - KRSTić, p. 247-248, pl. 66, figs 1-2. 1972 Cypria siboviki KRSTIĆ - SOKAČ, pp. 64, pl. 24, figs 15-16, 19. 1975 Cypria siboviki KRSTIĆ - KRSTIĆ, p. 195-196, pl. 1, figs 1-2. 1975 Cypria aff. siboviki KRSTIĆ - KRSTIĆ, pl. 1, fig. 3. 
Material: Danitzpuszta pit (2 valves)

Dimensions: $\mathrm{L}=485-500.1 \mu \mathrm{m}, \mathrm{H}=350-373.215 \mu \mathrm{m}$, $\mathrm{L} / \mathrm{H}=1.340-1,386$

Stratigraphic range and geographic distribution: lower Pannonian of the Pannonian Basin: Mt. Medvednica in Croatia (SoKAČ 1972); Velika Moštanica, Sibovik 7/2 in Serbia (KRSTIĆ 1968b, 1975).

Family Cyprididae BAIRD 1845

Genus Herpetocyprella DADAY 1909

\section{Herpetocyprella auriculata (REUss, 1850) Plate II, fig. 2}

1850 Cypridina auriculata n. sp. - Reuss, p. 51, pl. 8, fig. 8 . 1991 Hungarocypris auriculata (REUSS) - SZUROMI-KoRECZ, pp. $225-228$, pl. 17, figs $1-8$, cum syn.

2008 Herpetocyprella auriculata (REUSS) - DANIELOPOL et al., p. 152 , text-figs 2 C, D; 3A, C; 4 A-C, 10 D, E.

2011 Hungarocypris auriculata (REUSS) - OltEANU, pl. 1, figs 2, 4-7, 9-10.

2016 Herpetocyprella auriculata (Reuss) - KovÁcs et al., pl. 1, figs 6-10.

Materials: Danitzpuszta pit (35 valves); Danitzpuszta trench (22 valves)

Dimensions: $\mathrm{L}=1166-675 \mu \mathrm{m} \mathrm{H}=646-875 \mu \mathrm{m}, \mathrm{L} / \mathrm{H}=$ 1.805-1.914

Stratigraphic range and geographic distribution: Pannonian of the Pannonian Basin system: Vienna (Reuss 1850) and Sankt Margarethen (DANIELOPOL et al. 2008) in Austria; Muteniče, Svatoborice, Hodonín, Stavěšice in the Czech Republic (PoKORNÝ 1944, 1952; JIŘIČEK 1983, 1985; DANIELOPOL et al. 2008); Sopron, Tengelic, Nagykozárd, Máriakéménd, Tisztaberek in Hungary (MéHES 1907, ZaLÁNyi 1944, SZÉles 1982, SZuROMi-KoreCZ 1991); Mt. Medvednica in Croatia (SoKAČ 1972); Belgrade, Velika Moštanica, Sibovik 9, Đurinci in Serbia (KRSTIĆ 1973b, 1985); Holod, Şoimi (OlTEANU 2011), Gârbovița, and Cunța (Kovács et al. 2016) in Transylvania, Romania.

\section{Herpetocyprella hieroglyphica (MéHES, 1907) Plate II, fig. 3-4}

1907 Cypris hieroglyphica n. sp. - MÉHES, p. 508, pl. 3, figs 15-19. 1991 Hungarocypris hieroglyphica (MÉHES) - SZUROMI-KorECZ, pp. 228-230, pl. 18, figs 1-2, cum syn.

2008 Herpetocyprella hieroglyphica (MÉHES) - DANIELOPOL et al., p. 153 , text-fig. 11.

2011 Hungarocypris hieroglyphica (MÉHes) - OLTEANU, pl. 1, figs $1,3,8$.

2016 Herpetocyprella hieroglyphica (MÉHES) - Kovács et al., pl. 1, figs $1-5$.

Materials: Danitzpuszta pit (25 valves); Danitzpuszta trench (13 valves)

Dimensions: $\mathrm{L}=950.438-1807.306 \mu \mathrm{m} \mathrm{H}=561.818-$ $909.175 \mu \mathrm{m}, \mathrm{L} / \mathrm{H}=1,691-1,987$

Stratigraphic range and geographic distribution: lower Pannonian of the Pannonian Basin system: Danube-Tisza Interfluve in Hungary (SZÉLES 1963); Hodonín (JIŘIČEK 1985) and Stavěšice (DANIELOPOL et al. 2008) in the Czech
Republic; Mt. Medvednica in Croatia (SOKAČ 1967, 1972); Vrčin, Karagača creek in Serbia (KRSTIĆ 1960, 1973b, 1985); Szócsán/Soceni (MÉHES 1907, DANIElOPOL et al. 2008), Şoimi, Holod (OlteAnu 1971, 2011), Lopadea, Gârbovița, Cunța (Kovács et al. 2016) in Transylvania, Romania.

Subfamily Cypridopsinae BRONSTEIN 1947

Genus Amplocypris ZALÁNYI 1944

\section{Amplocypris abscissa (REUSs, 1850) Plate II, fig. 5}

1972 Amplocypris abscissa (REUSs) - SoKAČ, p. 36, pl. 11, figs 2, 4, 6; pl. 13, figs 2, 4, 5-6.

1973c. Amplocypris abscissa (REUSS) - KRSTIĆ, pp. 102-103, pl. 1 fig. 4; pl. 4, figs 3-4, pl. 8, fig. 1.

1983 Amplocypris abscissa (REUSS) - JIŘIČEK, pl. 6, fig. 36.

1985 Amplocypris abscissa (REUSs) - JIŘIČEK, p. 393, pl. 51, figs $13-15$.

1989 Amplocypris abscissa (REUSS) - OltEANU, pl. 1, fig. 16.

2011 Amplocypris abscissa (REUSS) - DANIELOPOL et al., text-figs $1 \mathrm{~A}-\mathrm{B}, 2,3,7-10$.

2011 Amplocypris aff. abscissa (Reuss) - OltEAnU, pl. 5, fig. 5; pl. 22 , fig. 5.

Material: Danitzpuszta pit (22 valves)

Dimensions: $\mathrm{L}=726.027-1082.241 \mu \mathrm{m} \mathrm{H}=356.025$ $553.896 \mu \mathrm{m}, \mathrm{L} / \mathrm{H}=1.954-2.039$

Stratigraphic range and geographic distribution: lower Pannonian of the Pannonian Basin: Hodonín in the Czech Republic (JIŘIČEK 1983, 1985); Sankt Margarethen, Hennersdorf in Austria (DANIELOPOL et al. 2011); Mt. Medvednica in Croatia (SOKAČ 1972); Belgrade in Serbia (KRSTIĆ 1973c); Sinteşti in Transylvania, Romania (OlteAnu 1989, 2011).

Amplocypris major KRSTIĆ, 1973 Plate II, fig. 6

1972 Amplocypris major KRSTIĆ - SOKAČ, p. 36, pl. 13, figs 1-3. 1973c. Amplocypris major - KRSTIĆ, pp. 100-102, figs 61-65; pl. 5, figs 1-2.

1985 Amplocypris major KRSTIĆ - KRSTIĆ, pl. 5, figs 6-8.

2011 Amplocypris major KRSTIĆ - OltEAnU, pl. 4, fig. 3.

Material: Danitzpuszta pit (5 valves)

Dimensions: $\mathrm{L}=964.906-1331 \mu \mathrm{m} \mathrm{H}=516.333-653$ $\mu \mathrm{m}, \mathrm{L} / \mathrm{H}=1.869-2.038$

Stratigraphic range and geographic distribution: Pannonian of the Pannonian Basin: Mt. Medvednica in Croatia (SoKAČ 1972); Belgrade in Serbia (KRSTIĆ 1973c, 1985); Soceni in Transylvania, Romania (Olteanu 2011).

\section{Amplocypris firmus KRSTIĆ, 1973 Plate II, fig. 7}

1973c. Amplocypris firmus n. sp. - KRSTÍ́, pp. 103-104, pl. 1, fig. $1 ;$ pl. 3, fig. 2; pl. 10 figs $1-3$.

1973c. Amplocypris cf. firmus KRSTIĆ - KRSTIĆ, pl. 8, fig. 4. 1985 Amplocypris firmus - KRSTIĆ, pl. 6, fig. 4.

2013 Amplocypris ex. gr. firmus KRSTIĆ - TER BORGH et al., fig. 7/1. 2016 Amplocypris firmus KRSTIĆ - KovÁCs et al., pl. 1, figs 15-19. 
Material: Danitzpuszta trench (7 valves)

Dimensions: $\mathrm{L}=825-1082.267 \mu \mathrm{m} \mathrm{H}=375-540.935$ $\mu \mathrm{m}, \mathrm{L} / \mathrm{H}=2.001-2.2$

Stratigraphic range and geographic distribution: lower Pannonian of the Pannonian Basin system: Velika Moštanica, Sibovik 7/2, Beočin, Đurinci in Serbia (KRSTIĆ 1973c; TER BORGH et al. 2013); Gârbovița, Cunța in Transylvania, Romania (KovÁcs et al. 2016).

\section{Amplocypris recta (REUSS, 1850)}

Plate II, fig. 8

1850 Cytherina recta n. sp. - Reuss, p. 52, pl. 8, fig. 11.

1972 Amplocypris recta (REUSS) - SoKAČ, p. 35, pl. 11, figs 5, 7-8.

1973c. Amplocypris recta (Rss.) - KRstić, p. 113, pl. 3, fig. 1; pl.

16 , figs 6-7.

1973c. Amplocypris ex. gr. recta (Rss.) - KRSTIĆ, p. 113, pl. 16 figs 4-5. 1982 Amplocypris recta REUSS - SzÉLES, p. 246, pl. 7, figs 4-5.

1982 Amplocypris aff. recta REUSS - SzÉLES, pp. 246-247, pl. 7,

fig. 6 ; pl. 7, figs 1,3 .

1983 Amplocypris recta (REUSS) - JIŘIČEK, pl. 6, fig. 35.

1985 Amplocypris aff. recta (REUSS) - JIŘIČEK, p.392, pl. 51, figs $10-12$.
1985 Amplocypris recta (REUSS) - KRSTIĆ, pl. 15, fig. 1.

1998 Amplocypris recta (REUSs) - KovAČ et al., pl. 4, fig. 9.

1998 Amplocypris recta (REUSs) - PIPíK \& HoleC, pl. 1, figs 1-2.

2004 Amplocypris recta (REUSs) - PIPÍK et al., pl. 1, fig. 14.

2011 Amplocypris recta - DANIELOPOL et al., fig. 4.

2011 Amplocypris recta (REUSS) - OltEANU, pl. 22, fig. 7.

Materials: Danitzpuszta pit (3 valves); Danitzpuszta trench (34 valves)

Diemensions: $\mathrm{L}=631,410-1717,526 \mu \mathrm{m}, \mathrm{H}=331,675-$ $867,911 \mu \mathrm{m}, \mathrm{L} / \mathrm{H}=1,904-1,979$

Stratigraphic range and geographic distribution: Pannonian of the Pannonian Basin system: Moosbrunn (REuss 1850) and Sankt Margarethen (DANIELOPOL et al. 2011) in Austria; Studienka (PIPÍK et al. 2004), Borský Svätý Jur (PiPík \& Holec 1998), and boreholes in the Vienna Basin (KovaČ et al. 1998) in Slovakia; Hodonín in the Czech Republic (JIŘIČEK 1983, 1985); Tengelic in Hungary (SzÉLES 1982); Mt. Medvednica in Croatia (SoKAČ 1972); Đurinci in Serbia (KRSTIĆ 1973c, 1985); Şoimi in Transylvania, Romania (OlteAnu 2011). 